\title{
Sources, solubility, and dry deposition of aerosol trace elements over the East China Sea
}

\author{
Shih-Chieh Hsu ${ }^{\text {a,* }}$, George T.F. Wong a , Gwo-Ching Gong ${ }^{b}$, Fuh-Kwo Shiah ${ }^{\text {a,b }}$, Yi-Tang Huang a,c, \\ Shuh-Ji Kao ${ }^{\text {a }}$, Fujung Tsai ${ }^{\mathrm{d}}$, Shih-Chun Candice Lung ${ }^{\mathrm{a}, \mathrm{e}}$, Fei-Jan Lin ${ }^{\mathrm{c}}$, I-I Lin ${ }^{\mathrm{e}}$, \\ Chin-Chang Hung ${ }^{b}$, Chun-Mao Tseng ${ }^{c}$ \\ ${ }^{a}$ Research Center for Environmental Changes, Academia Sinica, Taipei, Taiwan, ROC \\ b Institute of Marine Environmental Chemistry and Ecology, National Taiwan Ocean University, Keelung, Taiwan, ROC \\ c Institute of Oceanography, National Taiwan University, Taipei, Taiwan, ROC \\ d Department of Marine Environmental Informatics, National Taiwan Ocean University, Keelung, Taiwan, ROC \\ e Department of Atmospheric Sciences, National Taiwan University, Taipei, Taiwan, ROC
}

\section{A R T I C L E I N F O}

\section{Article history:}

Received 25 February 2008

Received in revised form 8 October 2008

Accepted 9 October 2008

Available online $\mathrm{xxxx}$

\section{Keywords:}

Asian dust

East China Sea

Solubility

Dry deposition

Trace elements

Phosphorus

Nitrogen

\begin{abstract}
A B S T R A C T
A total of 47 marine aerosols collected from the East China Sea between the spring of 2005 and the spring of 2007 were analyzed for both the water-soluble and the total concentrations of 25 trace elements and phosphorus and the water-soluble major ions, organic carbon, as well as silicon. During the sampling periods, eight samples were significantly influenced by Asian dust events. The total concentrations of both the chemical species of dust origin and of anthropogenic origin were higher during the Asian dust period, suggesting that the Asian outflow of air pollutants often accompanies the Asian dust advection. Overall, the average solubilities were $\leq 20 \%$ for $\mathrm{Al}, \mathrm{Fe}, \mathrm{Ti}, \mathrm{Cr}, \mathrm{Y}, \mathrm{Sn}, \mathrm{Ba}, \mathrm{Ni}, \mathrm{Ga}$, and $\mathrm{Mo}$; $20-40 \%$ for Co, Cs, Rb, Sb, and Pb; 40-60\% for Mn, V, Cu, Ge, and P; and $\geq 60 \%$ for Tl, Sr, As, Zn, Cd, and Se. The solubilities for many elements are lower in the high dust period than during the polluted northeasterly monsoon and the background summer period. A variety of controlling factors of the solubilities of the elements were discussed in this study. The relative importance could be concluded as follows: acid processing $>$ chemical speciation $\approx$ aerosol source $>$ dust loading. Finally, we estimated the dry depositional fluxes of soluble elements by assuming certain dry deposition velocities for each element. The fluxes were $39 \pm 50 \mu \mathrm{gg} / \mathrm{m}^{2} / \mathrm{d}$ for soluble Fe and $41 \pm$ $74 \mu \mathrm{g} / \mathrm{m}^{2} / \mathrm{d}$ for the combination of some bioavailable elements (e.g., $\mathrm{Zn}, \mathrm{Cu}, \mathrm{Mn}, \mathrm{Ba}, \mathrm{Co}, \mathrm{V}, \mathrm{Ni}$, and Cd) during the northeasterly monsoon. Atmospheric deposition is an additional source of nutrient elements that may be important not only in the coastal/marginal sea, but also particularly in the remote open ocean because aerosol trace elements are associated mostly with fine mode particles that can be brought farther from the source regions.
\end{abstract}

(C) 2008 Elsevier B.V. All rights reserved.

\section{Introduction}

It is widely documented that transition trace metals, such as Fe, $\mathrm{Mn}, \mathrm{Co}, \mathrm{Zn}, \mathrm{Cu}$, and $\mathrm{Ni}$ are essential nutrients to marine biota (Butler, 1998; Whitfield, 1998). In the remote oceans, particularly in the highnitrate low-chlorophyll (HNLC) areas of the open oceans, atmospheric depositions are a vital source of bioavailable Fe and trace elements and bring about biological stimulation (Bishop et al., 2002; Jickells et al., 2005). Recent field measurements have shown that the enhancement in nitrogen fixation and biological blooms in the remote oceans corresponds to the episodic supply by atmospheric deposition (Baker et al., 2003; Yuan and Zhang, 2006).

Asian dust storms annually occur in the late winter and spring in three primary dust regions, namely, the Gobi Desert, the Taklamakan

\footnotetext{
* Corresponding author. Tel.: +886 $226539885 x 530$; fax: +886 227833584 . E-mail address: schsu815@rcec.sinica.edu.tw (S.-C. Hsu).
}

Desert, and the Loess Plateau. Zhang et al. (1997) estimated China's annual emission of dusts to be $800 \mathrm{Tg}$, $50 \%$ of which is subject to longrange transport to the Pacific Ocean and beyond. In addition to this, large quantities of air pollutants, which include particulate matter, $\mathrm{SO}_{2}$, and $\mathrm{NO}_{x}$, are spewed out from mainland China, owing to its rapid industrial development and urbanization since the '80s (Carmichael et al., 2002; Wang et al., 2004 and references therein). When the cold high pressure systems, which develop in Siberia and Northern China between late October and early May, move southeastward out of the China continent, the northeasterly monsoon prevails south of $30^{\circ} \mathrm{N}$ following the passage of the cold front (Lin et al., 2005; Hsu et al., 2008a). Consequently, when Asian dust storms occur in Northern China, Asian dust is lifted and transported southward (Hsu et al., 2004, 2008a). Like Asian dust, air pollutants could also be spread by transport agents out of the main continent particularly when the moving atmospheric systems pass over the urban and industrial cities. Hence, there is a high deposition rate of Asian dust as well as other air pollutants over the East China Sea (ECS) as it is situated right next to 
Table 1

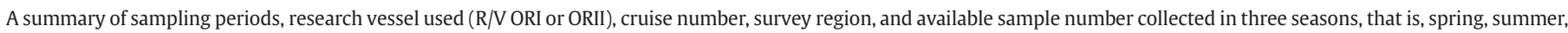
and early winter

\begin{tabular}{|c|c|c|c|c|}
\hline Season & Research vessel_Cruise & Sampling period & Survey region & Sample number \\
\hline Spring & $\begin{array}{l}\text { R/V ORII_1270; } 1271 ; 1273 ; 1337 ; \\
\text { 1338; } 1340 ; 1343 ; 1344 ; 1421 ; \\
1422 ; 1424 ; 1428\end{array}$ & $\begin{array}{l}\text { 2005: } 3 / 18-3 / 22 ; 3 / 25-3 / 29 ; 4 / 14-4 / 18 \\
\text { 2006: 3/17-3/20; 3/20-3/24; 3/28-3/30; 4/8-4/9; 4/12-4/13 } \\
\text { 2007: 3/16-3/17; 3/19-3/24; 3/27-3/31; 4/9-4/14 }\end{array}$ & The southern ECS & 33 \\
\hline Summer & R/V OR_756 & $6 / 10-6 / 17 / 2005$ & The whole ECS & 7 \\
\hline Winter & R/V OR_815 & $11 / 6-11 / 15 / 2006$ & The whole ECS & 7 \\
\hline
\end{tabular}

the Chinese mainland (Duce et al., 1991; Zhang et al., 1997; Gao et al., 2001). As a result, the atmospheric depositions of both nutrients and toxic species may have a substantial impact on its biogeochemistry, especially with respect to biological bloom and the cycling and budget balance of certain elements. For example, Lin et al. (2000) found that the dissolvable $\mathrm{Pb}$ in the surface layer of the southern ECS was the highest reported for the oceans and linearly proportional to the atmospheric deposition flux of eolian $\mathrm{Pb}$. They then suggested that the ECS has been contaminated by airborne anthropogenic substances from Asian outflows, resulting in the disturbance of biogeochemical cycling of $\mathrm{Pb}$ in the sea. However, very little is known about the atmospheric depositions of trace metals to the ECS, although it is situated between the open North Pacific Ocean and the region considered as the main source of Asian dust and other air pollutants.

In order to accurately assess the biogeochemical impact of the atmospheric input, atmospheric particulate species of interest must be determined for the bioavailable soluble fraction rather than only for the total concentrations. The percentage of the amount that can be dissolved, referred to as "solubility," is species-dependent and is controlled by various controlling factors. These factors include the following: (1) the pH of the extracting medium (Statham and Chester, 1988; Lim et al., 1994; Chester et al., 1997, 2000a,b; Desboeufs et al., 1999); (2) the enrichment factor $\left(\mathrm{EF}_{\text {crust }}\right)$ of the element relative to its natural crustal abundance (Chester et al., 1993a; Guerzoni et al., 1999); (3) the particle loading in the solution (Guerzoni et al., 1999); (4) aerosol types and sizes (Davison et al., 1994; Chester et al., 1993a, 1997); (5) photoreduction (Zhuang et al., 1992; Zhu et al., 1993); (6) clouding/aging processing (Mackie et al., 2005); and (7) the presence of organic, acidic, or carbonaceous substances (Zuo, 1995; Desboeufs et al., 2001, 2005). Their relative importance is variable (e.g., Zhuang et al., 1992; Zhu et al., 1993; Hsu et al., 2005a; Chen et al., 2006; Baker et al., 2006) and as such depends on which solutions (such as rainwater, cloud water, fresh water, or seawater) interact with aerosols, which compositions and/or sources dominate aerosols, and which specific metals are of interest. So far, the literature/data on the solubility of marine aerosol-associated metals are limited and mostly concentrate on the Atlantic Ocean and the Mediterranean Sea (Statham and Chester, 1988; Kersten et al., 1991; Chester et al., 1993a; Guieu et al., 1994; Bonnet and Guieu, 2004; Baker et al., 2006), with little data being reported on the Western Pacific Ocean (Zhuang et al., 1992; Hsu et al., 2005a; Buck et al., 2006). Consequently, the likely effects of trace element deposition on marine biogeochemistry are yet to be quantitatively assessed. Aerosol trace metals of anthropogenic origins mostly are associated with fine particles. In contrast, $\mathrm{Fe}$ (also $\mathrm{Al}$ ) is associated mainly with the coarse mineral dust particles. The trace metals in the anthropogenic fine particles can be transported farther away from their sources than those mainly associated with the coarse mineral dust particles, such as Fe. On the other hand, atmospheric depositions of toxic metals, which usually have high mobility, may substantially affect the marine eco-environment (e.g., Lin et al. 2000). Accordingly, we must quantify the contributions of aerosol water soluble trace elements (WSTEs), as well as Fe, to the ocean.

This study is a component of the integrated project called Longterm Observation and Research of the ECS (otherwise known as LORECS) of Taiwan. In this study, the total suspended particulate (TSP) marine aerosol samples were collected on board ship primarily over the southern ECS during spring (33 samples), summer (seven samples), and early winter (seven samples) cruises between 2005 and 2007 (Table 1 and Fig. 1). The total dissolvable concentrations of a suite of metal elements (Al, Fe, Na, Mg, K, Ca, Mn, Sr, Ba, Ti, Mn, Rb, Co, $\mathrm{Ni}, \mathrm{Cr}, \mathrm{V}, \mathrm{Y}, \mathrm{Cs}, \mathrm{Zn}, \mathrm{Cu}, \mathrm{Cd}, \mathrm{Pb}, \mathrm{Sn}, \mathrm{Sb}, \mathrm{Se}, \mathrm{As}, \mathrm{Mo}, \mathrm{Ge}, \mathrm{Ga}$, and Tl) were analyzed. Hereafter, the total and soluble fractions of a given element are presented as $X_{T}$ and $X_{S}$, respectively. In addition, phosphorus, water-soluble silicon $\left(\mathrm{Si}_{\mathrm{S}}\right)$, water-soluble ionic species $\left(\mathrm{NH}_{4}^{+}, \mathrm{SO}_{4}^{2-}, \mathrm{NO}_{3}^{-}\right.$, and $\mathrm{Cl}^{-}$), and water-soluble organic carbon (WSOC) were also determined. Thus, temporal distributions of the chemical species were constructed. The solubilities of selected trace metals were calculated. The dry deposition fluxes of WSTEs during the northeasterly monsoon period were quantified. The controlling factors of aerosol trace metal dissolution and the biogeochemical implications of atmospheric deposition of selected nutrient species were discussed. Data on Fe were published elsewhere (Hsu et al., 2008b) and hence is not discussed here, but its deposition flux is calculated and reported.

\section{Materials and methods}

\subsection{Sampling}

A total of 47 TSP marine aerosol samples were collected on board the R/V Ocean ResearcherII (ORII) and R/V Ocean ResearcherI (ORI) over the

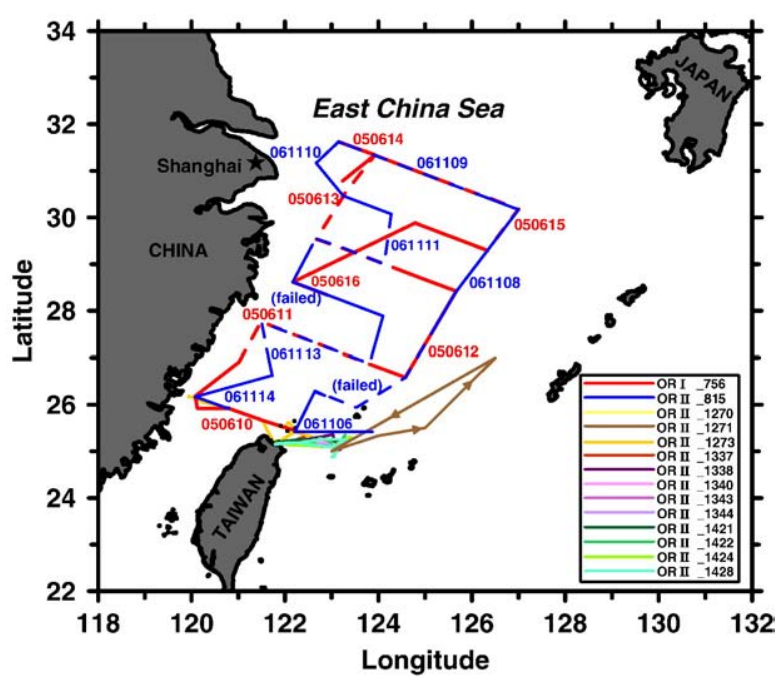

Fig. 1. Regional map and ship tracks for 14 investigated cruises over the East China Sea (ECS) between the spring of 2005 and the spring of 2007. A total of 12 springtime cruises were mostly conducted in the southern ECS. The accurate periods for these cruises are given in Table 1. For the two cruises, June 2005 and November 2006, occupied over nearly the whole ECS, with the red and blue lines (solid and dashed lines) indicating the ship tracks, respectively. The sample identifications in bold numbers (yymmdd) indicate the starting dates of sampling for each sample and are shown aside from the solid/ dashed red/blue lines, representing the sampling track for a given sample indicated. During the November 2006 cruise, the sampling for two samples failed, as indicated. (For interpretation of the references to color in this figure legend, the reader is referred to the web version of this article.) 
ECS between 2005 and 2007, of which 33 samples were collected from 12 springtime cruises, seven samples from a summer cruise, and seven samples from a winter cruise. The exact date and time of each cruise are shown in Table 1, along with the ship tracks which are shown in Fig. 1. The aerosol sampler used was the TSP high-volume air sampler (Tisch Environmental, Inc.), and it was set up on the upper foredeck (10 m above sea level for R/V ORII and $14 \mathrm{~m}$ for R/V ORI) and operated at a nearly constant flow-rate of 40 cubit feet per minute (CFM). The sampling time for most samples was around $24 \mathrm{~h}$, but for several other samples the time was shorter or longer than $24 \mathrm{~h}$. The aerosol particles were collected on Whatman ${ }^{\circledR} 41$ cellulose filters $\left(8^{\prime \prime} \times 10^{\prime \prime}\right)$ (Whatman Limited, Maidstone, UK). In this study, November was considered as early winter when the dataset was subdivided into three seasonal groups: spring, winter, and summer, which are usually characterized by high dust, high pollution, and background seasons, respectively, in this study region.

\subsection{Chemical analysis}

The filter was subdivided into eight equal pieces. For the concentrations of dissolvable material, a piece of the filter was extracted with $25 \mathrm{ml}$ of Milli-Q water ( $\mathrm{pH} \sim 6.5$ ) on a reciprocating shaker for $0.5 \mathrm{~h}$ and at rest for an additional $0.5 \mathrm{~h}$ at room temperature $\left(25^{\circ} \mathrm{C}\right)$. Previous studies showed that the amount of metals leached reaches a constant maximum in 0.5 to $1 \mathrm{~h}$ (Kersten et al., 1991; Guerzoni et al., 1999; Hsu et al., 2005a). Thus, a leaching time of $\sim 1 \mathrm{~h}$ was adopted here. The extract was filtered through a polycarbonate membrane filter $(0.4 \mu \mathrm{m}$ pore size and $47 \mathrm{~mm}$ in diameter from Nuclepore). The filter was rinsed three times with Milli-Q water. The extract together with the rinsings were then diluted to a known final volume (almost around $48 \mathrm{ml}$ ) and then used for the determination of the ionic species $(5 \mathrm{ml})$, WSOC $(3 \mathrm{ml})$, and WSTE ( $40 \mathrm{ml})$. The solutions for the determinations of WSOC and WSTE were acidified to $0.5 \%$ and $1 \%$ with $\mathrm{H}_{3} \mathrm{PO}_{4}$ and $\mathrm{HNO}_{3}$ (ultra-pure grade from Merck), respectively. For the concentrations of total metal, another piece of the filter was digested with an acid mixture $\left(4 \mathrm{ml} \mathrm{HNO}_{3}+2 \mathrm{ml}\right.$ HF; all ultra-pure grades from Merck) using an ultra-high throughput microwave digestion system (MARSXpress, CEM; Corporation, Matthews, NC). Details on the microwave digestion were given elsewhere (Hsu et al., 2008a). The efficiency of the digestion scheme was checked by subjecting a certain amount of a standard reference material (SRM 1648, urban particulate matter, National Institute of Standards and Technology (NIST), USA) to the same treatment.

Major water-soluble ionic species $\left(\mathrm{Cl}^{-}, \mathrm{SO}_{4}^{2-}, \mathrm{NO}_{3}^{-}\right.$, and $\left.\mathrm{NH}_{4}^{+}\right)$were analyzed by ion chromatography using a Dionex model ICS-90 (for anion) and a model ICS-1500 (for cation) ion chromatograph equipped

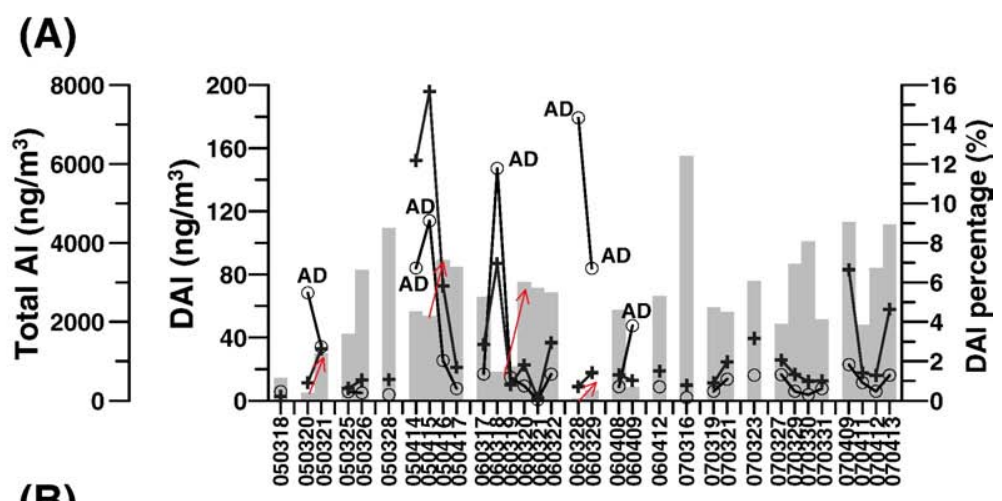

(B)
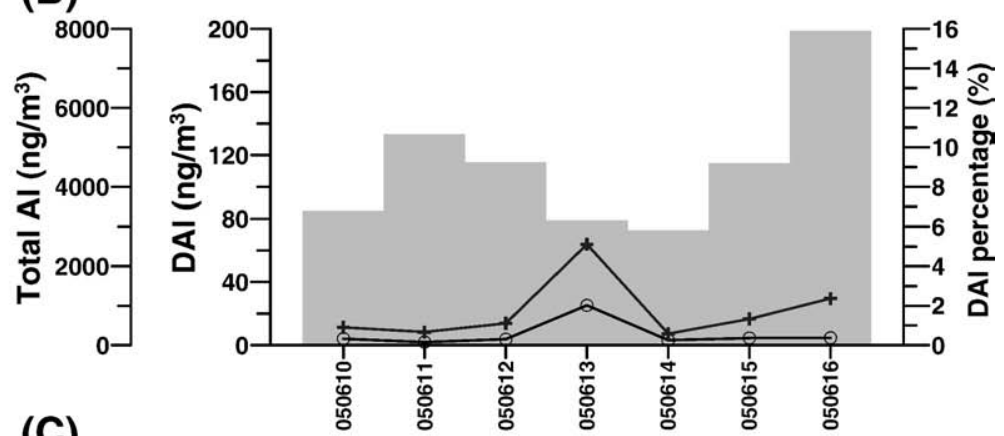

(C)
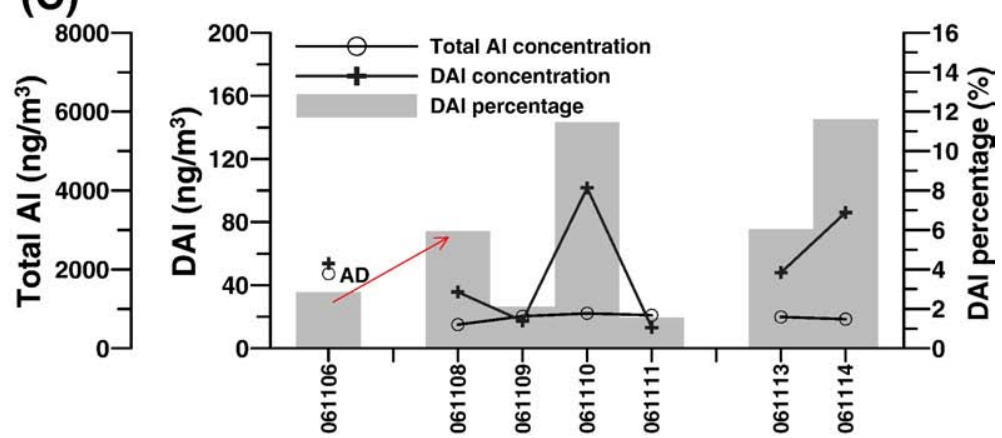

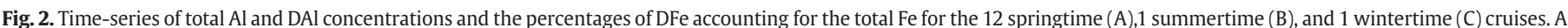

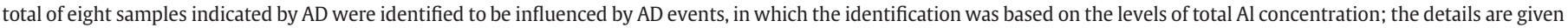

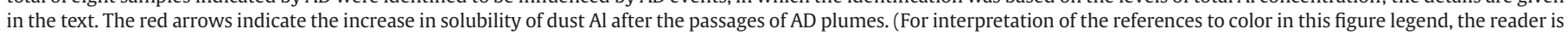
referred to the web version of this article.) 

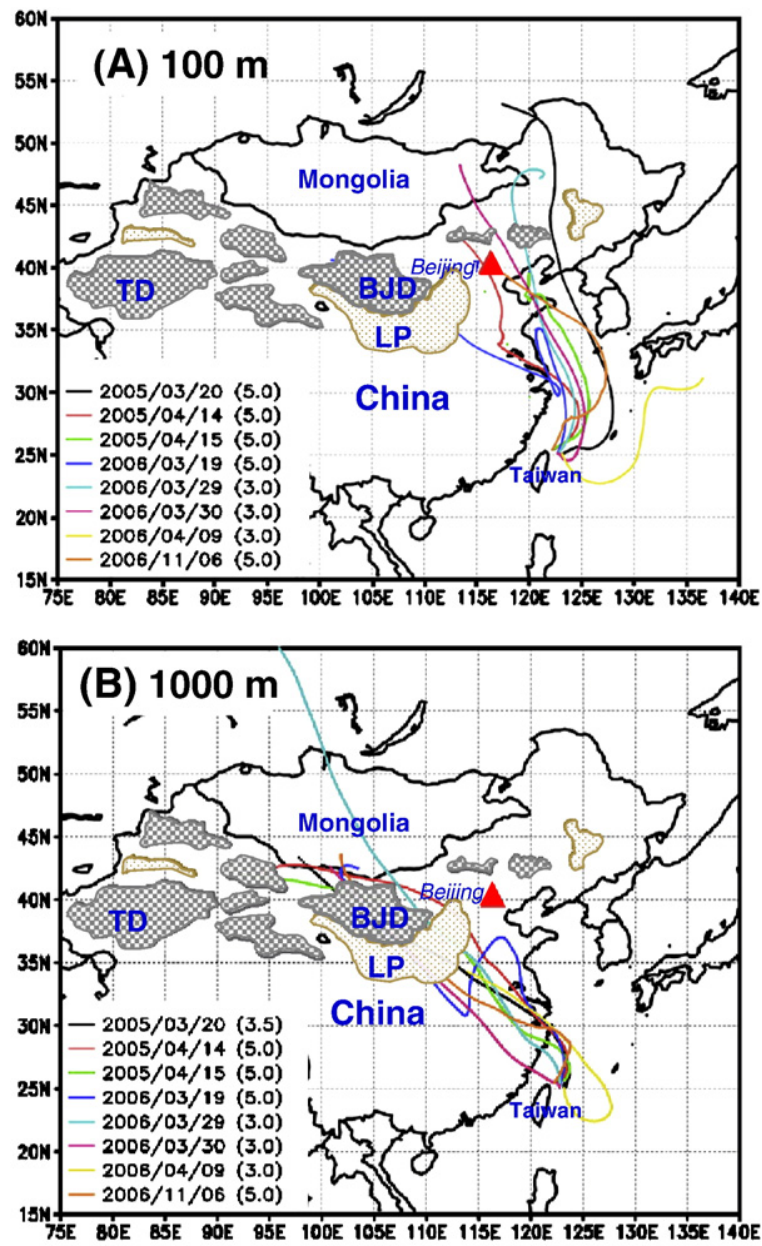

Fig. 3. Results of backward air-mass trajectory analysis at two elevations (100 and $1000 \mathrm{~m}$ ) for three to five days for the identified eight Asian dust days using the HYSPLIT modeling calculations of NOAA. Numbers in parentheses in the legends of each plot represent the days that the trajectory analyses were calculated. The Badain-Juran Desert (BJD), Loess Plateau (LP), and Taklamakan Desert (TD) are indicated.

with a conductivity detector (ASRS-ULTRA). Soluble major metal ions $\left(\mathrm{Na}^{+}, \mathrm{Mg}^{2+}, \mathrm{K}^{+}\right.$, and $\left.\mathrm{Ca}^{2+}\right)$ were analyzed by inductively coupled plasmamass spectrometry (ICP-MS) using a Perkin Elmer model Elan 6100 quadrupole-based inductively coupled plasma mass spectrophotometer. The detailed procedures for ion chromatography were presented in Hsu et al. (2007). WSOC was measured by converting organic carbon to carbon dioxide by wet digestion and then analyzing the carbon dioxide formed by using a total organic carbon analyzer (O.I. Analytical Model 1010). The soluble and total concentrations of the trace elements and the concentration of soluble Si were also determined by ICP-MS. The recoveries of a large majority of the elements in the SRM 1648 by the digestion with the $\mathrm{HNO}_{3}$-HF mixture fell within $\pm 10 \%(n=5)$ of the certified values. For the other elements, $\mathrm{Se}, \mathrm{As}, \mathrm{Cs}, \mathrm{Sb}$, and $\mathrm{Rb}$ fell within $\pm 15 \%$, with only noncertified values available for the latter three elements. The digestion solution of the SRM 1648 was also analyzed by ICP-MS at the beginning and at the end of each batch of samples. The total concentrations of the elements were then corrected for any overestimation or underestimation from their average recoveries in the SRM 1648 standard reference material. Reagent and procedural blanks were determined empirically and were then also corrected. Details regarding the ICP-MS analysis were described elsewhere (Hsu et al., 2005b, 2006, 2008a). In the soluble fraction, the detection limits of the elements are at least two orders of magnitude lower than the sample concentration. In the total concentrations, the detection limits are at least one order of magnitude lower than the sample concentrations.

\subsection{Calculations of solubility and $E F_{\text {crust }}$ value and the PCA analysis}

The solubility for a given element was calculated as follows:

Solubility $(\%)=C_{\mathrm{S}} / C_{\mathrm{T}} \times 100 \%$

where $C_{\mathrm{S}}$ and $C_{\mathrm{T}}$ are the soluble and total concentrations, respectively. The solubility derived from the Milli-Q water extraction may be different from and somewhat higher than those derived from seawater extraction, particularly for dust-derived elements, such as $\mathrm{Al}$ and $\mathrm{Fe}$. That is because of the difference in $\mathrm{pH}$ of the medium used (Chen et al., 2006). Nevertheless, the estimated solubilities from this study would still be useful in assessing the bioavailability and environmental mobility of certain elements.

The degree to which a given element $(\mathrm{X})$ in an aerosol is enriched or depleted relative to a specific source can be assessed using an enrichment factor $(E F)$. It has been the practice to categorize trace elements in marine aerosols on the basis of their crustal EF, calculated by using the following equation (e.g., Chester et al., 1993a; Hsu et al., 2004, 2005b):

$\mathrm{EF}_{\text {crust }}=\left(C_{\mathrm{X}} / C_{\mathrm{Al}}\right)_{\text {aerosol }} /\left(C_{\mathrm{X}} / C_{\mathrm{Al}}\right)_{\text {crust }}$

where $\left(C_{\mathrm{X}} / C_{\mathrm{Al}}\right)_{\text {aerosol }}$ is the concentration ratio of a given element $\mathrm{X}$ to $\mathrm{Al}$ in aerosols, and $\left(C_{\mathrm{X}} / C_{\mathrm{Al}}\right)_{\text {crust }}$ is the concentration ratio of a given element $\mathrm{X}$ to $\mathrm{Al}$ in the average crustal abundance (Taylor, 1964). However, Kersten et al. (1991) emphasized that EF values should only be treated as significant only in orders of magnitude.

In the current study, the principal component analysis (PCA; Statistical Analysis System, SAS version 8.2, SAS Institute Inc., Cary, NC)

Table 2

Statistical summary (mean \pm S.D.) of atmospheric concentrations $\left(\mathrm{ng} / \mathrm{m}^{3}\right)$ for WSTEs, major ionic species and WSOC for the $\mathrm{NE}_{\mathrm{NAD}}$ group samples

\begin{tabular}{|c|c|c|c|c|c|}
\hline & $\mathrm{NE}_{\mathrm{NAD}}(n=32)$ & $\mathrm{NE}_{\mathrm{AD}}(n=8)$ & Winter $(n=7)$ & Spring $(n=33)$ & Summer $(n=7)$ \\
\hline$\overline{\mathrm{Al}}$ & $21 \pm 25$ & 1.8 & 2.0 & 1.0 & 0.8 \\
\hline $\mathrm{Fe}$ & $21 \pm 22$ & 1.5 & 1.9 & 1.0 & 0.8 \\
\hline $\mathrm{Ti}$ & $2.5 \pm 1.5$ & 4.9 & 1.8 & 1.3 & 0.6 \\
\hline $\mathrm{Sr}$ & $4.8 \pm 3.1$ & 3.6 & 1.4 & 1.3 & 0.6 \\
\hline $\mathrm{Ba}$ & $1.2 \pm 1.1$ & 4.2 & 2.2 & 1.2 & 1.0 \\
\hline Mn & $5.5 \pm 7.1$ & 5.6 & 2.8 & 1.2 & 0.6 \\
\hline V & $1.7 \pm 5.1$ & 1.0 & 1.6 & 0.9 & 3.0 \\
\hline $\mathrm{Rb}$ & $0.62 \pm 1.16$ & 4.0 & 3.1 & 1.1 & 0.8 \\
\hline $\mathrm{Ni}$ & $0.27 \pm 0.37$ & 1.0 & 1.3 & 0.9 & 1.8 \\
\hline $\mathrm{Cr}$ & $0.24 \pm 0.21$ & 1.8 & 1.8 & 1.0 & 1.0 \\
\hline Co & $0.063 \pm 0.066$ & 3.3 & 1.9 & 1.2 & 0.9 \\
\hline Y & $0.015 \pm 0.020$ & 4.5 & 2.2 & 1.2 & 0.6 \\
\hline Cs & $0.044 \pm 0.125$ & 3.1 & 4.0 & 1.0 & 0.7 \\
\hline $\mathrm{Cu}$ & $28 \pm 35$ & 0.8 & 2.2 & 0.8 & 4.6 \\
\hline $\mathrm{Zn}$ & $38 \pm 89$ & 2.3 & 3.0 & 1.0 & 0.6 \\
\hline $\mathrm{Pb}$ & $5.6 \pm 15.0$ & 1.2 & 3.4 & 0.8 & 1.2 \\
\hline As & $0.74 \pm 1.14$ & 2.8 & 2.5 & 1.1 & 0.6 \\
\hline Se & $0.51 \pm 0.81$ & 2.9 & 2.7 & 1.1 & 1.2 \\
\hline $\mathrm{Cd}$ & $0.36 \pm 0.57$ & 2.9 & 3.0 & 1.0 & 0.5 \\
\hline $\mathrm{Sb}$ & $0.17 \pm 0.32$ & 2.6 & 2.5 & 1.0 & 0.7 \\
\hline $\mathrm{Ga}$ & $0.13 \pm 0.27$ & 2.4 & 3.0 & 1.0 & 0.7 \\
\hline Sn & $0.060 \pm 0.112$ & 2.1 & 2.3 & 1.0 & 0.9 \\
\hline $\mathrm{Tl}$ & $0.063 \pm 0.140$ & 3.0 & 3.7 & 1.0 & 0.8 \\
\hline Ge & $0.028 \pm 0.058$ & 3.5 & 3.2 & 1.1 & 0.6 \\
\hline Mo & $0.040 \pm 0.095$ & 8.0 & 1.4 & 1.6 & 0.8 \\
\hline $\mathrm{Si}$ & $5.2 \pm 2.9$ & 1.9 & 1.3 & 1.1 & 0.4 \\
\hline$P$ & $6.4 \pm 6.1$ & 2.6 & 2.2 & 1.1 & 0.8 \\
\hline $\mathrm{Na}^{+}$ & $4238 \pm 3426$ & 1.6 & 1.3 & 1.1 & 0.7 \\
\hline $\mathrm{Mg}^{2+}$ & $521 \pm 409$ & 1.9 & 1.3 & 1.1 & 0.6 \\
\hline $\mathrm{K}^{+}$ & $304 \pm 266$ & 2.8 & 2.2 & 1.1 & 0.8 \\
\hline $\mathrm{Ca}^{2+}$ & $441 \pm 282$ & 5.6 & 1.9 & 1.3 & 0.5 \\
\hline $\mathrm{NH}_{4}^{+}$ & $1598 \pm 1356$ & 2.0 & 1.6 & 1.1 & 1.1 \\
\hline $\mathrm{Cl}^{-}$ & $5241 \pm 6513$ & 1.9 & 1.3 & 1.1 & 0.4 \\
\hline $\mathrm{NO}_{3}^{-}$ & $2355 \pm 2774$ & 2.2 & 2.0 & 1.0 & 1.0 \\
\hline $\mathrm{SO}_{4}^{2-}$ & $6061 \pm 4309$ & 2.3 & 1.6 & 1.1 & 1.1 \\
\hline $\mathrm{nss} \mathrm{SO}_{4}^{2-}$ & $4555 \pm 4272$ & 2.0 & 1.7 & 1.1 & 1.7 \\
\hline WSOC & $997 \pm 1197$ & 2.4 & 1.8 & 1.1 & 1.3 \\
\hline
\end{tabular}

For other groups, the values represent the concentration ratio relative to the $\mathrm{NE}_{\mathrm{NAD}}$ group. 
was used for assessing the associations among chemical species. The data were standardized beforehand to have zero mean and unit variance. This was performed by utilizing the orthogonal transformation method with Varimax rotation. Only those components with eigenvalue greater than unity were retained, because they can account for a meaningful amount of variance. The retained components have undergone rotation and then used in this study. Factor loadings indicate the correlation of each species with each component and are related to the source emission composition.

\section{Results and discussion}

\subsection{Data statistics and temporal distribution}

The data sets were subdivided into three groups according to the sampling time: spring, summer, and early winter. Moreover, by adopting a criterion of $1500 \mathrm{ng} / \mathrm{m}^{3}$ of Al as an indication of the occurrence of a significant Asian dust event (Hsu et al., 2008a), a total of eight events could be identified during the sampling period (Fig. 2). The northeasterly monsoon prevails in both the winter and the spring, while the southeasterly monsoon prevails during summer. According to the prevailing wind and the occurrences of Asian dust events, the samples collected in the spring and the winter were further subdivided into two groups: the $\mathrm{NE}_{\mathrm{AD}}$ (the Asian dust period in the $\mathrm{NE}$ monsoon) and $\mathrm{NE}_{\mathrm{NAD}}$ (the non Asian dust period in the NE monsoon) groups. During the Asian dust events, the air mass back trajectories were analyzed by employing the HYSPLIT modeling calculation of NOAA. In agreement with previous studies (Hsu et al., 2008a; Liu et al., in press), the analyses reveal that the source regions of the Asian dust are located in and around the Gobi Desert and Loess Plateau (Fig. 3). The statistical summary of the soluble and total concentrations of the various elements and ions are given in Tables 2 and 3, respectively. For comparison, we have compiled literature/data on the total concentrations for selected metals from several oceanic regions in Table 4 . The values found in this study are quite comparable to those reported in other oceanic regions. In the case of the water-soluble fraction (Table 2), the mean concentrations during the Asian dust periods are much higher than those in the non-Asian dust periods as well as other seasons for all major ionic species and silicon. For the metals, the temporal patterns are more variable. The elements found to have the highest concentrations during the Asian dust period include $\mathrm{Ti}, \mathrm{Sr}, \mathrm{Ba}, \mathrm{Mn}, \mathrm{Co}, \mathrm{Y}$, and $\mathrm{Se}$ Similar concentrations of $\mathrm{Al}, \mathrm{Fe}, \mathrm{Cr}, \mathrm{As}, \mathrm{Cd}, \mathrm{Sb}, \mathrm{Sn}, \mathrm{Ge}$, and $\mathrm{P}$ were found during the Asian dust period and in the winter. Maximum concentrations of $\mathrm{Zn}$ and $\mathrm{Pb}$ were found in the winter and this is consistent with our long-term measurements in northern Taiwan (Hsu et al., 2005b, 2006). In contrast, the maximum concentrations of $\mathrm{V}, \mathrm{Ni}$, and $\mathrm{Cu}$ were apparent in the summer. However, the total concentrations of all the elements, with the exception of $\mathrm{Cu}$ and $\mathrm{Zn}$, were much higher during the Asian dust period. Elevated

Table 3

As in Table 2, but for the total fraction

\begin{tabular}{|c|c|c|c|c|c|}
\hline & $\mathrm{NE}_{\mathrm{NAD}}(n=32)$ & $\mathrm{NE}_{\mathrm{AD}}(n=8)$ & Winter $(n=7)$ & Spring $(n=33)$ & Summer $(n=7)$ \\
\hline$\overline{\mathrm{Al}}$ & $399 \pm 314$ & 8.7 & 2.2 & 1.4 & 0.5 \\
\hline $\mathrm{Fe}$ & $268 \pm 238$ & 8.3 & 2.7 & 1.4 & 0.7 \\
\hline $\mathrm{Ti}$ & $30 \pm 27$ & 7.6 & 2.6 & 1.3 & 0.7 \\
\hline $\mathrm{Sr}$ & $7.2 \pm 4.9$ & 4.5 & 1.9 & 1.3 & 0.6 \\
\hline $\mathrm{Ba}$ & $5.1 \pm 8.0$ & 7.6 & 3.4 & 1.3 & 1.5 \\
\hline Mn & $11 \pm 12$ & 7.0 & 3.1 & 1.3 & 0.6 \\
\hline V & $3.0 \pm 8.8$ & 3.0 & 2.3 & 1.1 & 2.4 \\
\hline $\mathrm{Rb}$ & $1.4 \pm 1.9$ & 7.8 & 3.1 & 1.3 & 0.5 \\
\hline $\mathrm{Ni}$ & $1.1 \pm 1.0$ & 5.1 & 2.2 & 1.3 & 1.1 \\
\hline $\mathrm{Cr}$ & $3.1 \pm 4.3$ & 2.7 & 1.9 & 1.1 & 0.5 \\
\hline Co & $0.18 \pm 0.15$ & 6.1 & 2.4 & 1.3 & 0.7 \\
\hline Y & $0.12 \pm 0.13$ & 9.5 & 3.2 & 1.3 & 0.3 \\
\hline Cs & $0.10 \pm 0.16$ & 7.3 & 3.5 & 1.2 & 0.4 \\
\hline $\mathrm{Cu}$ & $54 \pm 78$ & 1.5 & 2.9 & 0.9 & 3.7 \\
\hline $\mathrm{Zn}$ & $41 \pm 94$ & 3.0 & 3.5 & 1.0 & 0.7 \\
\hline $\mathrm{Pb}$ & $12 \pm 21$ & 4.8 & 3.6 & 1.1 & 0.9 \\
\hline As & $0.85 \pm 1.4$ & 5.0 & 2.8 & 1.2 & 0.7 \\
\hline $\mathrm{Se}$ & $0.57 \pm 0.94$ & 3.7 & 3.1 & 1.1 & 1.5 \\
\hline $\mathrm{Cd}$ & $0.37 \pm 0.60$ & 4.4 & 3.4 & 1.1 & 0.6 \\
\hline $\mathrm{Sb}$ & $0.47 \pm 0.82$ & 3.4 & 2.8 & 1.1 & 0.8 \\
\hline $\mathrm{Ga}$ & $0.48 \pm 0.75$ & 6.9 & 3.8 & 1.2 & 0.9 \\
\hline Sn & $0.58 \pm 1.1$ & 3.9 & 3.3 & 1.1 & 0.9 \\
\hline $\mathrm{Tl}$ & $0.086 \pm 0.17$ & 4.5 & 3.7 & 1.1 & 0.8 \\
\hline $\mathrm{Ge}$ & $0.057 \pm 0.11$ & 5.0 & 3.6 & 1.1 & 0.6 \\
\hline Mo & $0.22 \pm 0.37$ & 5.0 & 3.0 & 1.2 & 0.9 \\
\hline $\mathrm{P}$ & $10 \pm 8.4$ & 5.7 & 2.4 & 1.3 & 0.9 \\
\hline $\mathrm{Na}$ & $4706 \pm 3878$ & 1.7 & 1.2 & 1.1 & 0.7 \\
\hline $\mathrm{Mg}$ & $658 \pm 454$ & 3.1 & 1.2 & 1.3 & 0.7 \\
\hline K & $436 \pm 303$ & 4.4 & 2.1 & 1.2 & 0.8 \\
\hline $\mathrm{Ca}$ & $538 \pm 328$ & 6.3 & 2.0 & 1.3 & 0.6 \\
\hline
\end{tabular}

Table 4

Comparison of aerosol metal mean concentrations $\left(\mathrm{ng} / \mathrm{m}^{3}\right)$ in the total fraction between the East China Sea (the northeasterly monsoon period) and other oceanic regions

\begin{tabular}{lllll}
\hline & $\begin{array}{l}\text { East China } \\
\text { Sea (this work) }\end{array}$ & $\begin{array}{l}\text { Irish Sea } \\
\text { (Liverpool, UK) } \\
\text { (Chester et al., 2000b) }\end{array}$ & $\begin{array}{l}\text { Mediterranean Sea } \\
\text { (Tel Shikmona, Israel) } \\
\text { (Kocak et al., 2004) }\end{array}$ & $\begin{array}{l}\text { Gulf of Aqaba, } \\
\text { Red Sea } \\
\text { (Chen et al., 2008) }\end{array}$ \\
\hline $\mathrm{Al}$ & 615 & 317 & 952 & 1081 \\
$\mathrm{Fe}$ & 410 & 340 & 724 & 683 \\
$\mathrm{~K}$ & 588 & - & - & 633 \\
$\mathrm{Mn}$ & 16 & 8.4 & 16.7 & 16.7 \\
$\mathrm{~V}$ & 3.8 & 7.3 & - & 5.4 \\
$\mathrm{Co}$ & 0.25 & 0.42 & - & 0.3 \\
$\mathrm{Ni}$ & 1.5 & 3.0 & - & 2.8 \\
$\mathrm{Cr}$ & 3.7 & 2.1 & 2.3 & 3.0 \\
$\mathrm{Cu}$ & 58 & 21 & 5.9 & 3.4 \\
$\mathrm{Zn}$ & 51 & 36 & 22.4 & 14.9 \\
$\mathrm{~Pb}$ & 17 & 43 & 24.9 & 7.0 \\
$\mathrm{Cd}$ & 0.50 & - & 0.22 & 0.1 \\
\hline
\end{tabular}

concentrations were specifically observed in the crust-originated elements $\mathrm{Al}, \mathrm{Fe}, \mathrm{Ca}, \mathrm{Ti}$, $\mathrm{Sr}, \mathrm{Ba}, \mathrm{Mn}, \mathrm{Rb}, \mathrm{Co}, \mathrm{Y}$, and Cs (Table 3). In general, it was found that the total concentrations for most metals in the spring are comparable with those reported at Cheju Island, South Korea (Chen et al., 1997). This suggests that most of the particulate species analyzed had common sources (source regions) and/or were subject to similar transport processes (Park et al., 2004). High concentration of anthropogenic species sulfate, nitrate, and ammonium, occurred in the downstream marine areas during the Asian dust period. Zhang et al. (2005) emphasized the significance of dust particles as a medium for pollutant conversion and transportation.

Elemental solubilities are summarized in Table 5. Dust-derived elements $\mathrm{Al}$ and $\mathrm{Fe}$ had comparable values ranging between $5 \%$ and $10 \%$, but during the Asian dust period, the values decreased to $1.1 \pm 1.8 \%$ for $\mathrm{Al}$ and $1.4 \pm 2.0 \%$ for $\mathrm{Fe}$. The solubility for $\mathrm{Al}$ and $\mathrm{Fe}$ is very consistent with that observed in the northwest Pacific Ocean, although it is slightly higher than that found in seawater extractions (Buck et al., 2006). For most of the anthropogenic metals $\mathrm{Zn}, \mathrm{Cd}, \mathrm{Cu}, \mathrm{Pb}, \mathrm{As}$, and $\mathrm{Se}$, the solubilities reached $\sim 30-80 \%$. Surprisingly, the solubility for Sn was only $\sim 10 \%$, although it is a well-documented anthropogenic element. The solubility of $\mathrm{P}$ was up to $\sim 50 \%$. During the Asian dust period, it was around $30 \%$. These values are rather comparable to those ( $32 \%)$ observed in the Atlantic Ocean (Baker et al., 2006). In the case of other dust-dominated elements (i.e., Ti, Sr, Ba, Co, Mn, Rb, Cs, and Y), the solubilities appeared to be variable, ranging from as low as $10 \%$ (i.e., $\mathrm{Y}$ and $\mathrm{Ti}$ ) to as high as $50 \%$ (i.e., $\mathrm{Sr}$ and $\mathrm{Mn}$ ).

\subsection{Source identification}

In this study, we applied three approaches to identify the likely sources of trace metals in aerosols: (1) by performing a PCA, (2) by examining any correlations among the species, and (3) by calculating the crustal EF of the elements. The results from the principal component analyses of the soluble and total fractions are given in Tables 6 and 7 , respectively. The results of the crustal EF calculation for each element in the total fraction are depicted in Fig. 4. Overall, the PCA results for the water-soluble and the total fractions agree well with each other. They show that the principal sources include continental dust and anthropogenic sources through long-range transport, sea salt, biofuel/coal combustion, heavy fuel combustion, and metalliferous industries. Crustal EF values for crustally derived elements ( $\mathrm{Fe}, \mathrm{Y}, \mathrm{Ti}$, and $\mathrm{Co}$ ) were all around unity. In contrast, anthropogenically derived elemental $\mathrm{EF}$ (Tl, Mo, $\mathrm{Sn}, \mathrm{As}, \mathrm{Zn}, \mathrm{Cu}, \mathrm{Pb}, \mathrm{Sb}, \mathrm{Cd}$, and $\mathrm{Se}$ ) were $>10$. For mixed sourcedominated elements ( $\mathrm{Mn}, \mathrm{P}, \mathrm{Ba}, \mathrm{Rb}, \mathrm{Cs}, \mathrm{K}, \mathrm{Ni}, \mathrm{V}, \mathrm{Cs}, \mathrm{Cr}, \mathrm{Ge}$, and $\mathrm{Ga}$ ), the enrichment factors were between 2 and 10 (Fig. 4 and Table 8). Accordingly, combining the PCA and EF results, the chemical species may be categorized into four distinct groups: dust-dominated elements, sea salt-dominated element, anthropogenic species, and dust/anthropogenic mixed source-dominated elements.

A strong correlation was found between both total and soluble $\mathrm{Al}$ and $\mathrm{Fe}$ (Fig. 5). This suggests the domination of dust origin for aerosol Fe (Chen and Siefert, 2004). The mean $\mathrm{Fe} / \mathrm{Al}$ ratio in the total fraction for the northeasterly monsoon samples $(n=40)$ is 0.61 , which is quite consistent with those $(\sim 0.60)$ measured in the northern China desert and loess areas (Zhang et al., 2003). This is also consistent with the results of airmass trajectory analysis, which indicate that the likely sources of the Asian dust were located in and around the Gobi Desert and the Loess Plateau (Fig. 3). The mean Fe/Al ratio in the soluble fraction, 0.76 , is slightly higher than that for the total fraction, suggesting that the solubility for $\mathrm{Fe}$ (5.5\% in the northeasterly monsoon period and $11 \%$ in summer) is higher than that (4\% in the northeasterly monsoon period and $9 \%$ in summer) for $\mathrm{Al}$. In addition, $\mathrm{Fe}_{\mathrm{s}}$ correlated well with nss-sulfate and WSOC (Hsu et al., 2008b), which is also reflected in the PCA results (Table 6). Hsu et al. (2008b) suggested that the dissolution of Fe in the dust was enhanced by acid processing, and/or a minor fraction of $\mathrm{Fe}_{\mathrm{S}}$ might have originated from the same anthropogenic sources as nsssulfate and WSOC. In addition, most of WSTEs also correlated well with nss-sulfate and WSOC (Table 8). Similarly, the two instead may be responsible for the correlations observed. For instance, the two possibilities appear to be similarly important for the mixed source-contributed element Mn. For anthropogenic source-dominated elements, including $\mathrm{Zn}, \mathrm{Pb}, \mathrm{Sb}, \mathrm{As}$, and $\mathrm{Se}$, the correlations may be a result of the same sources as 
Table 5

Statistical summary of the solubility (mean \pm S.D.; in unit \%) for selected aerosol elements in the $\mathrm{NE}_{\mathrm{NAD}}$ group samples over the East China Sea

\begin{tabular}{lcllll}
\hline & $\mathrm{NE}_{\mathrm{NAD}}(n=32)$ & $\mathrm{NE}_{\mathrm{AD}}(n=8)$ & Winter $(n=7)$ & Spring $(n=33)$ & Summer $(n=7)$ \\
\hline $\mathrm{Al}$ & $5.1 \pm 2.8$ & 0.2 & 0.9 & 0.7 & 1.7 \\
$\mathrm{Fe}$ & $7.7 \pm 4.5$ & 0.2 & 0.7 & 0.7 & 1.5 \\
$\mathrm{Ti}$ & $8.4 \pm 5.6$ & 0.6 & 0.7 & 1.0 & 0.8 \\
$\mathrm{Sr}$ & $67 \pm 14$ & 0.8 & 0.7 & 1.0 & 1.0 \\
$\mathrm{Ba}$ & $23 \pm 10$ & 0.6 & 0.6 & 1.0 & 0.6 \\
$\mathrm{Mn}$ & $49 \pm 12$ & 0.8 & 0.9 & 1.0 & 1.1 \\
$\mathrm{~V}$ & $55 \pm 16$ & 0.3 & 0.7 & 0.8 & 1.3 \\
$\mathrm{Rb}$ & $45 \pm 16$ & 0.5 & 1.0 & 0.9 & 1.5 \\
$\mathrm{Ni}$ & $26 \pm 17$ & 0.2 & 0.6 & 0.7 & 1.6 \\
$\mathrm{Cr}$ & $7.8 \pm 5.4$ & 0.7 & 0.9 & 0.9 & 2.2 \\
$\mathrm{Co}$ & $36 \pm 12$ & 0.5 & 0.8 & 0.9 & 1.3 \\
$\mathrm{Y}$ & $13 \pm 6.1$ & 0.5 & 0.7 & 0.9 & 1.7 \\
$\mathrm{Cs}$ & $44 \pm 20$ & 0.4 & 1.1 & 0.8 & 1.7 \\
$\mathrm{Cu}$ & $51 \pm 12$ & 0.6 & 0.8 & 0.9 & 1.3 \\
$\mathrm{Zn}$ & $84 \pm 18$ & 0.8 & 0.7 & 1.0 & 1.0 \\
$\mathrm{~Pb}$ & $45 \pm 16$ & 0.2 & 0.9 & 0.7 & 1.3 \\
$\mathrm{As}$ & $86 \pm 10$ & 0.6 & 0.9 & 0.9 & 0.9 \\
$\mathrm{Se}$ & $86 \pm 16$ & 0.8 & 0.9 & 1.0 & 0.9 \\
$\mathrm{Cd}$ & $87 \pm 13$ & 0.7 & 1.0 & 0.9 & 1.0 \\
$\mathrm{Sb}$ & $36 \pm 7$ & 0.8 & 0.9 & 1.0 & 0.9 \\
$\mathrm{Ga}$ & $27 \pm 11$ & 0.3 & 0.8 & 0.8 & 0.8 \\
$\mathrm{Sn}$ & $10.4 \pm 3.7$ & 0.5 & 0.7 & 0.9 & 1.1 \\
$\mathrm{Tl}$ & $73 \pm 14$ & 0.7 & 1.0 & 0.9 & 1.0 \\
$\mathrm{Ge}$ & $50 \pm 11$ & 0.7 & 0.9 & 0.9 & 1.1 \\
$\mathrm{Mo}$ & $17 \pm 9$ & 1.7 & 0.5 & 1.4 & 1.0 \\
$\mathrm{P}$ & $61 \pm 22$ & 0.5 & 0.9 & 0.8 & 0.9 \\
\hline $\mathrm{For}$ & & & & & \\
\hline
\end{tabular}

For other groups, the values indicate the ratio relative to the $\mathrm{NE}_{\mathrm{AD}}$ group.

sulfate, particularly biofuel/coal combustion. Phosphorus is an essential nutrient to marine phytoplankton, and therefore better understanding on its sources and dissolution behaviors is required to assess its impact. Nevertheless, atmospheric contributions of phosphorus may not be a vital source of inorganic phosphorus in the ECS (Chen and Chen, 2008). As shown in Table 8, PS correlated well with nss-sulfate, nitrate, nss- $\mathrm{K}^{+}$, and $\mathrm{Se}$. In general, Se in the atmosphere primarily originates from coal combustion, and thus, is usually used as a tracer of coal combustion (e.g., Wen and Carignan, 2007). K-rich aerosol particles are frequently detected in China, which is attributed to the substantial contribution of coal combustion, with coal being the most common fuel source in China (Waldman et al., 1991; Wei et al., 1999). It is also suggested that coal combustion essentially account for the pronounced levels of anthropogenic sulfate. Accordingly, the majority of $\mathrm{P}_{\mathrm{S}}$ may originate from anthropogenic activities. Based on the solubility of $\sim 50 \%$ and the crustal EF value of around 2 , it could be concluded that approximately half of aerosol-associated phosphorus derives from the continental source, whereas another half comes from anthropogenic sources.

\subsection{Controlling factors of dissolution}

\subsubsection{Acid processing}

Almost all WSTEs correlated well with nss-sulfate, nitrate, and WSOC, as revealed in a correlation matrix table (Table 8). The good correlations suggest that they may originate from the same sources (or source regions) and experience the same transport processes (cold high-pressure system and the northeasterly monsoon wind) and/or that the dissolution of aerosol elements were enhanced by the presence of acidic constituents. Indeed, it was observed that sulfate and nitrate frequently associate within dust particles, likely existing as coatings on the surface of dust mainly through heterogeneous reactions of acidic gases (e.g., sulfuric and nitric acids) and dust during Asian outflows (Zhang et al., 2005; Sullivan et al., 2007). Zhuang et al. (1992) suggested that the close coupling of dust and sulfate could largely enhance the dissolution of dust Fe to increase the supply of bioavailable Fe in the remote oceans. Hence, acid processing would increase the dissolution not only of dust-associated Fe but also of many aerosol elements of both natural and anthropogenic origins. By employing a model simulation, Meskhidze et al. (2005) found that the dissolution of Asian dust Fe could be enhanced once the dust plume associated with high levels of anthropogenic $\mathrm{SO}_{2}$ emission (i.e. high $\mathrm{SO}_{2}$ to dust mixing ratio). In addition, acidification of aerosol particles may be enhanced by photochemical reaction and cloud processing, which will be discussed further in Sections 3.3.4 and 3.3.5.

\subsubsection{The origins of aerosol elements}

As mentioned above (Fig. 4), the crustal EF value was used to identify the predominant origins by which anthropogenic or natural sources dominated for aerosol elements. In order to assess the effect of elemental origins, we thus examined the correlations of the solubility with logarithmic EF value for each metal (Deguillaume et al., 2005). As a result, only a few metals, which include $\mathrm{Pb}, \mathrm{Ni}$, and $\mathrm{Ge}$ had moderate correlations (not shown), but with the exclusion of several outlier data points. When clustering all elements, as shown in Fig. 6, several features are identified, although the relationship between the two parameters is not so strong. Elements with crustal EF values of $\sim 1.0$ had low solubility of $\sim 10 \%$ and these elements include $\mathrm{Al}, \mathrm{Fe}, \mathrm{Ti}$, and Y. Co is an exceptional case, with a solubility reaching $\sim 30 \%$. Elements with high EF values of $\geq 100$ had high solubility ( $\geq 70 \%$ ), and these elements include $\mathrm{Tl}, \mathrm{As}, \mathrm{Zn}, \mathrm{Cd}$, and Se, while those with moderate solubility (30-50\%) include $\mathrm{Cu}, \mathrm{Pb}$, and $\mathrm{Sb}$. Elements with $\mathrm{EF}$ values of $2-10$ had variable solubility ranging from $\sim 10 \%$ to $\sim 65 \%$, and these elements include $\mathrm{Cr}(\sim 10 \%)$, Ni, Ba, Ga, Cs, Rb, V, Ge, Mn, P, and Sr ( 65\%). Similarly, elements with EF values of $10-100$ had variable solubility of $10-20 \%$ for Mo and Sn and $65 \%$ for Tl. This indicates that elements of anthropogenic origins characterized as high crustal EF may have high solubility, and on the contrary, dust-derived elements characterized as low crustal EF usually have low solubility.

Overall, this is deemed most consistent with the review results of Deguillaume et al. (2005). Nevertheless, from the results of our study, it could be concluded that the sources (or initial compositions) for aerosol elements are an important controlling factor for solubilization, but apparently not the key factor. Chester et al. (1993a) emphasized that the ranking of aerosol elemental solubility is not necessarily identical to their EF values. Furthermore, they suggested that the variations in solubility of selected metals are essentially speciation-mediated, which will be discussed further in Section 3.3.5.

\subsubsection{Dust loading}

Dust concentration and trace element solubility were examined. Dust concentration was converted from total $\mathrm{Al}$ concentration multiplying 12.5, assuming that $\mathrm{Al}$ abundance in dust particles is similar to the average crust composition, accounting for $8 \%$ (Taylor, 1964). Fe, Al, Ni, V, Rb, and P are among the trace metals examined that showed good correlations, as demonstrated in Fig. 7, of which Fe was taken from Hsu et al. (2008b). To some extent, all the six elements are essentially crustally derived ( $\mathrm{Al}, \mathrm{Fe}$, and $\mathrm{Rb}$ ) and dust/anthropogenic mixed source-dominated ( $\mathrm{Ni}, \mathrm{V}$, and $\mathrm{P}$ ) groups. Note that not one of the anthropogenic origin-dominated metals like As, $\mathrm{Zn}, \mathrm{Cd}, \mathrm{Sn}, \mathrm{Sb}$, and Se had such a correlation. A similar correlation has been observed previously, but mostly for aerosol Fe (Bonnet and Guieu, 2004; Hsu et al., 2005b; Sedwick et al., 2007). Some previous studies argued that such results could be artifacts resulting from the saturation of the leaching

\section{Table 6}

Orthogonal transformation rotated principal component matrix for the soluble chemical species of the northeasterly monsoon samples

\begin{tabular}{|c|c|c|c|c|}
\hline & Factor 1 & Factor 2 & Factor 3 & Factor 4 \\
\hline$\overline{\mathrm{Al}}$ & $0.81^{*}$ & 0.33 & - & - \\
\hline $\mathrm{Fe}$ & $0.81^{*}$ & 0.27 & - & 0.30 \\
\hline $\mathrm{Ti}$ & 0.38 & $0.85^{*}$ & 0.27 & - \\
\hline $\mathrm{Sr}$ & 0.27 & $0.71^{*}$ & $0.62 *$ & - \\
\hline $\mathrm{Ba}$ & $0.54^{*}$ & $0.79 *$ & - & - \\
\hline Mn & $0.58^{*}$ & $0.78^{*}$ & - & - \\
\hline V & - & - & - & $0.93^{*}$ \\
\hline $\mathrm{Rb}$ & $0.84^{*}$ & $0.51^{*}$ & - & - \\
\hline $\mathrm{Ni}$ & 0.34 & - & - & $0.89 *$ \\
\hline $\mathrm{Cr}$ & $0.85^{*}$ & 0.32 & - & 0.28 \\
\hline Co & $0.58 *$ & $0.74^{*}$ & - & - \\
\hline Y & $0.60 *$ & $0.74^{*}$ & - & - \\
\hline Cs & $0.91 *$ & 0.35 & - & - \\
\hline $\mathrm{Cu}$ & 0.33 & - & - & $0.70 *$ \\
\hline $\mathrm{Zn}$ & $0.79 *$ & - & - & - \\
\hline $\mathrm{Pb}$ & $0.94 *$ & - & - & - \\
\hline As & $0.85^{*}$ & $0.44^{*}$ & - & - \\
\hline $\mathrm{Se}$ & $0.87 *$ & $0.43 *$ & - & - \\
\hline $\mathrm{Cd}$ & $0.83^{*}$ & 0.38 & - & - \\
\hline $\mathrm{Sb}$ & $0.81^{*}$ & $0.45^{*}$ & - & - \\
\hline Ga & $0.92 *$ & - & - & - \\
\hline Sn & $0.83^{*}$ & 0.25 & - & - \\
\hline $\mathrm{Tl}$ & $0.90 *$ & 0.38 & - & - \\
\hline $\mathrm{Ge}$ & $0.86^{*}$ & $0.46^{*}$ & - & - \\
\hline Mo & $0.45^{*}$ & $0.69 *$ & 0.36 & - \\
\hline $\mathrm{P}$ & $0.76^{*}$ & $0.53 *$ & - & - \\
\hline $\mathrm{Si}$ & - & $0.70 *$ & - & - \\
\hline $\mathrm{Na}^{+}$ & - & - & $0.98^{*}$ & - \\
\hline $\mathrm{Mg}^{2+}$ & - & - & $0.97 *$ & - \\
\hline $\mathrm{K}^{+}$ & $0.69 *$ & $0.46^{*}$ & $0.50^{*}$ & - \\
\hline $\mathrm{Ca}^{2+}$ & 0.33 & $0.86^{*}$ & 0.30 & - \\
\hline $\mathrm{NH}_{4}^{+}$ & $0.74 *$ & $0.53 *$ & - & 0.26 \\
\hline $\mathrm{Cl}^{-}$ & - & - & $0.97 *$ & - \\
\hline $\mathrm{NO}_{3}^{-}$ & $0.50^{*}$ & $0.65^{*}$ & - & 0.39 \\
\hline $\mathrm{SO}_{4}^{2-}$ & $0.57 *$ & $0.63^{*}$ & - & 0.31 \\
\hline Nss-SO ${ }_{4}^{2-}$ & $0.60 *$ & $0.62 *$ & - & 0.30 \\
\hline WSOC & $0.80 *$ & 0.30 & - & - \\
\hline Likely source & $\begin{array}{l}\text { Continental } \\
\text { (dust/pollutant mixed) }\end{array}$ & $\begin{array}{l}\text { Dust } \\
\text { dominated }\end{array}$ & Sea salt & $\begin{array}{l}\text { Heavy fuel } \\
\text { combustior }\end{array}$ \\
\hline
\end{tabular}

Factor loadings smaller than \pm 0.25 are not given. Values greater than 0.40 are flagged by an ' $*$ '. 
Table 7

Orthogonal transformation rotated principal component matrix for the total fraction

\begin{tabular}{|c|c|c|c|}
\hline & Factor 1 & Factor 2 & Factor 3 \\
\hline$\overline{\mathrm{Al}}$ & $0.94 *$ & 0.29 & - \\
\hline $\mathrm{Fe}$ & $0.93 *$ & 0.36 & - \\
\hline $\mathrm{Ti}$ & $0.92 *$ & 0.31 & - \\
\hline $\mathrm{Sr}$ & $0.86^{*}$ & 0.30 & 0.40 \\
\hline $\mathrm{Ba}$ & $0.89 *$ & 0.35 & - \\
\hline Mn & $0.85^{*}$ & $0.50 *$ & - \\
\hline V & - & $0.53 *$ & - \\
\hline $\mathrm{Rb}$ & $0.84 *$ & $0.53 *$ & - \\
\hline $\mathrm{Ni}$ & $0.86^{*}$ & $0.42 *$ & - \\
\hline $\mathrm{Cr}$ & 0.37 & 0.39 & - \\
\hline Co & $0.90 *$ & $0.41 *$ & - \\
\hline Y & $0.93 *$ & 0.34 & - \\
\hline Cs & $0.73 *$ & $0.66^{*}$ & - \\
\hline $\mathrm{Cu}$ & - & 0.39 & $0.71^{*}$ \\
\hline $\mathrm{Zn}$ & - & $0.73^{*}$ & - \\
\hline $\mathrm{Pb}$ & $0.44 *$ & $0.88 *$ & - \\
\hline As & $0.54^{*}$ & $0.80 *$ & - \\
\hline Se & 0.31 & $0.91^{*}$ & - \\
\hline $\mathrm{Cd}$ & 0.36 & $0.86 *$ & - \\
\hline $\mathrm{Sb}$ & 0.33 & $0.91^{*}$ & - \\
\hline $\mathrm{Ga}$ & $0.76^{*}$ & $0.64 *$ & - \\
\hline Sn & 0.32 & $0.91^{*}$ & - \\
\hline $\mathrm{Tl}$ & 0.36 & $0.92 *$ & - \\
\hline $\mathrm{Ge}$ & $0.51^{*}$ & $0.84 *$ & - \\
\hline Mo & $0.47^{*}$ & $0.73 *$ & 0.34 \\
\hline TP & $0.89 *$ & $0.41^{*}$ & - \\
\hline $\mathrm{Na}$ & - & - & $0.90 *$ \\
\hline $\mathrm{Mg}$ & $0.66^{*}$ & - & $0.70^{*}$ \\
\hline K & $0.80 *$ & $0.51^{*}$ & 0.27 \\
\hline $\mathrm{Ca}$ & $0.93 *$ & 0.28 & - \\
\hline Likely source & Dust & $\begin{array}{l}\text { Pollution (Biofuel/coal/heavy fuel combustion and } \\
\text { metalliferous industries) }\end{array}$ & Sea salt \\
\hline
\end{tabular}

Factor loadings smaller than \pm 0.25 are not given. Values greater than 0.40 are flagged by an ' $*$ '.

solution with respect to the elements of interest at high-dust loadings (Zhuang et al., 1990; Baker et al., 2006). However, the fact that such trend is still being observed in studies that have used leaching/extraction methods designed to avoid saturation of the leaching solution (e.g., Buck et al., 2006; Sedwick et al., 2007; Wu et al., 2007) suggests that (at least partly) real.

Baker and Jickells (2006) ascribed this dust loading-solubility relationship to the effect of particle size and in turn the surface area to volume ratio of dust particle. As is well known, the concentration of dust particles usually exponentially decrease with travel time/distance during long-range transport (Meskhidze et al., 2005) and their mean size gradually decrease as coarser particles preferentially deposit, which mainly occurs within the first $1000 \mathrm{~km}$ far from the sources. Therefore, the decreased size of dust would have more surface area serving as sink of acid constituents leading to the increase in solubility for dust-derived elements, especially Fe. However, this dust loading effect seems to be insignificant to those anthropogenically derived elements. We inferred that most of the anthropogenic elements initially partition within fine aerosol particles; hence, the size fractionation (also the surface area to volume ratio) and loading effects would not be so important as dust-derived elements. Furthermore, in order to explain the inverse power-law relationship, Sedwick et al. (2007) proposed a mixing model between two distinct air masses characterized by significant differences in total Fe (i.e., dust loading) and Fe solubility. However, during our sampling period, the ECS was mostly under the influence of the prevailing northeasterly monsoon rather than of multiple air masses. This model seems to be inappropriate to our study.

\subsubsection{Aging/cloud processing}

A number of studies have demonstrated that clouding processes do have involvement in the dissolution of various aerosol species, including trace elements (e.g., Spokes et al., 1994; Deguillaume et al., 2005), with respect to several hydration/ evaporation (wetting/drying) cycles for aerosol particles during long-range transport (Desboeufs et al., 2001; Mackie et al., 2005). As illustrated in Fig. 2, during the Asian dust episodes, $\mathrm{Al}_{\mathrm{T}}$ concentration reached a maximum $\left(\sim 2000 \mathrm{ng} / \mathrm{m}^{3}\right.$ or more $)$ and $\mathrm{Al}_{\mathrm{S}}$ also usually reached a corresponding peak. When the Asian dust plumes passed, $\mathrm{Al}_{\mathrm{T}}$ sharply decreased, while $\mathrm{Al}_{\mathrm{S}}$ moderately decreased and in some cases increased. Therefore, in view of the solubility, the increasing tendency after the Asian dust events is more evident, as indicated by arrows in plots. This phenomenon was also pronounced for Fe, which has been hypothesized to be a consequence of aging/cloud processing (Hsu et al., 2008b). Indeed, during the Asian dust passage, the fronts often occupy around the study area as the high cold continental air mass encounters the hot wet maritime air mass, leading to thick clouds within the marine boundary layer. A major fraction of Asian dust and the associated pollution aerosols preferentially settled down and the remaining aerosols suspended for a longer period of time and perhaps underwent strong cloud processing, which also resulted in acidification of aerosol particles and enhancement in the aerosol dissolution. On the other hand, several studies demonstrated that dissolved transition metal ions are potentially serving as catalyst in the transformation of $\mathrm{SO}_{2}, \mathrm{O}_{3}$, and organic pollutants in clouds (Graedel et al., 1986; Sedlak et al., 1997). Consequently, the $\mathrm{pH}$ and acidic substances of cloud droplets would change and in turn affect the dissolution of aerosol metals (e.g., Desboeufs et al., 2001).

For comparison of aerosol element solubility (Fig. 8), we selected two studies from the UK, because such studies from China are not available: one in Birmingham (Birmili et al., 2006) and the other in Edinburgh ( $\mathrm{PM}_{10}$ samples; Heal et al., 2005). Notice that $\mathrm{Sn}$ in Birmingham aerosols similarly had a low water-soluble fraction, like ours. Surprisingly, the overall tendencies of selected elemental solubilities are similar to each other, while the magnitudes are somewhat different. When compared to the results of the two UK studies, the $\mathrm{NE}_{\mathrm{AD}}$ samples had lower solubilities, whereas the $\mathrm{NE}_{\mathrm{NAD}}$ samples had higher solubilities. We assumed that the aerosol elements sourced from major cities in China have similar solubilities (or dissolution properties) to those in the two cities of UK. By adopting a similar context as used in Zhuang et al. (1992), Pb, Cd, and As, which are typical elements of anthropogenic origins, had elevated crustal EF values during the Asian dust (112, 197, and 55, respectively) and non-Asian dust (203, 386 , and 97 , respectively) periods, indicating that they predominantly originated from anthropogenic sources, presumably comprising $>98 \%$ all the time. However, their solubilities had substantially increased from 11,63 , and $49 \%$ in the dust days to 45,87 , and $86 \%$ in the common days, respectively. This clearly suggests that the $\mathrm{NE}_{\mathrm{NAD}}$ samples must have been influenced by some kind of atmospheric process that enhances the

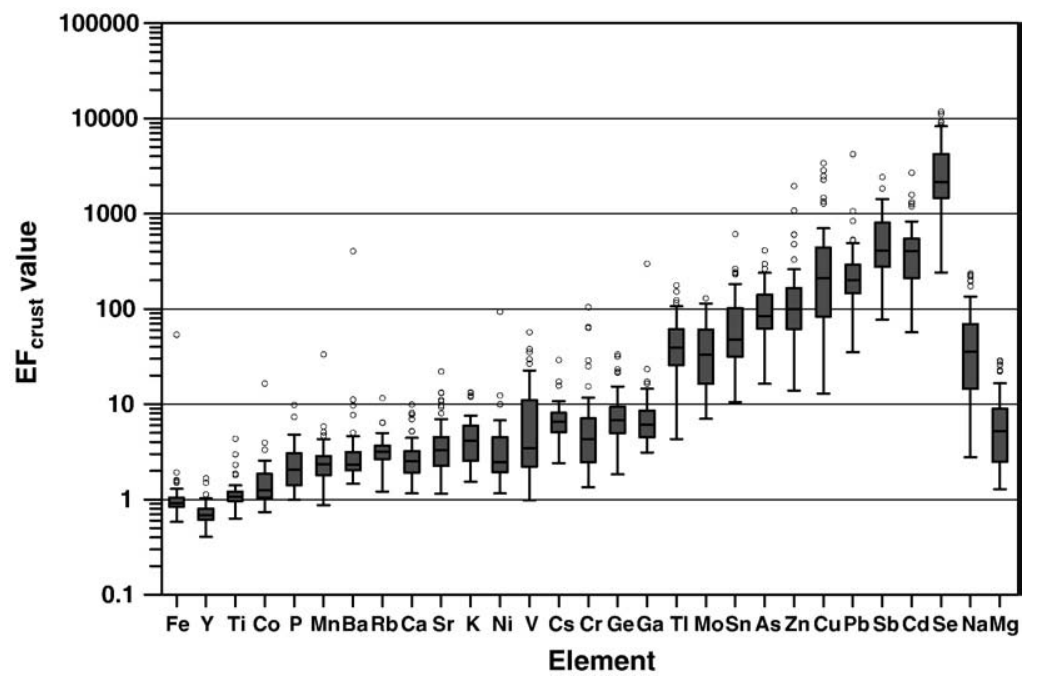

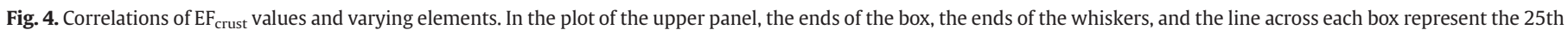
and 75th percentiles, the fifth and 95th percentiles, and the median, respectively; open circles indicate the data outliers. 
Table 8

A correlation matrix between WSTEs and ${ }_{n s s} \mathrm{SO}_{4}^{2-}, \mathrm{NO}_{3}^{-}$and WSOC concentrations

\begin{tabular}{llll}
\hline & ${ }_{n s s} \mathrm{SO}_{4}^{2-}$ & $\mathrm{NO}_{3}^{-}$ & WSOC \\
\hline $\mathrm{Al}$ & $\mathbf{0 . 8 3}$ & $\mathbf{0 . 6 0}$ & $\mathbf{0 . 8 0}$ \\
$\mathrm{Fe}$ & $\mathbf{0 . 8 2}$ & $\mathbf{0 . 6 4}$ & $\mathbf{0 . 7 8}$ \\
$\mathrm{Sr}$ & $\mathbf{0 . 5 6}$ & $\mathbf{0 . 4 8}$ & 0.37 \\
$\mathrm{Ba}$ & $\mathbf{0 . 8 0}$ & $\mathbf{0 . 7 5}$ & $\mathbf{0 . 6 7}$ \\
$\mathrm{Ti}$ & $\mathbf{0 . 7 1}$ & $\mathbf{0 . 6 2}$ & $\mathbf{0 . 5 2}$ \\
$\mathrm{Mn}$ & $\mathbf{0 . 8 2}$ & $\mathbf{0 . 7 5}$ & $\mathbf{0 . 6 5}$ \\
$\mathrm{Co}$ & $\mathbf{0 . 8 1}$ & $\mathbf{0 . 8 6}$ & $\mathbf{0 . 7 1}$ \\
$\mathrm{Ni}$ & $\mathbf{0 . 5 1}$ & $\mathbf{0 . 5 8}$ & $\mathbf{0 . 5 0}$ \\
$\mathrm{Cu}$ & 0.25 & 0.25 & 0.26 \\
$\mathrm{Zn}$ & $\mathbf{0 . 5 1}$ & $\mathbf{0 . 5 6}$ & $\mathbf{0 . 6 6}$ \\
$\mathrm{Cd}$ & $\mathbf{0 . 7 2}$ & $\mathbf{0 . 7 0}$ & $\mathbf{0 . 7 9}$ \\
$\mathrm{Sn}$ & $\mathbf{0 . 6 9}$ & $\mathbf{0 . 8 5}$ & $\mathbf{0 . 7 6}$ \\
$\mathrm{Sb}$ & $\mathbf{0 . 7 7}$ & $\mathbf{0 . 7 7}$ & $\mathbf{0 . 7 8}$ \\
$\mathrm{Tl}$ & $\mathbf{0 . 8 3}$ & $\mathbf{0 . 8 7}$ \\
$\mathrm{Pb}$ & $\mathbf{0 . 6 4}$ & $\mathbf{0 . 5 1}$ & $\mathbf{0 . 8 0}$ \\
$\mathrm{V}$ & $\mathbf{0 . 4 4}$ & $\mathbf{0 . 7 6}$ & 0.37 \\
$\mathrm{Cr}$ & $\mathbf{0 . 7 7}$ & $\mathbf{0 . 7 9}$ & $\mathbf{0 . 8 5}$ \\
$\mathrm{As}$ & $\mathbf{0 . 7 7}$ & $\mathbf{0 . 7 4}$ & $\mathbf{0 . 8 1}$ \\
$\mathrm{Y}$ & $\mathbf{0 . 8 8}$ & $\mathbf{0 . 7 5}$ & $\mathbf{0 . 6 8}$ \\
$\mathrm{Se}$ & $\mathbf{0 . 8 7}$ & $\mathbf{0 . 7 6}$ & $\mathbf{0 . 8 6}$ \\
$\mathrm{Ge}$ & $\mathbf{0 . 8 2}$ & $\mathbf{0 . 7 5}$ & $\mathbf{0 . 8 0}$ \\
$\mathrm{Rb}$ & $\mathbf{0 . 8 3}$ & $\mathbf{0 . 7 1}$ & $\mathbf{0 . 8 1}$ \\
$\mathrm{Cs}$ & $\mathbf{0 . 7 8}$ & $\mathbf{0 . 6 1}$ & $\mathbf{0 . 8 4}$ \\
$\mathrm{Ga}$ & $\mathbf{0 . 7 3}$ & $\mathbf{0 . 6 8}$ & $\mathbf{0 . 8 1}$ \\
$\mathrm{Mo}$ & $\mathbf{0 . 5 3}$ & $\mathbf{0 . 5 3}$ \\
$\mathrm{Si}$ & 0.63 & $\mathbf{0 . 8 1}$ & 0.31 \\
$\mathrm{P}$ & $\mathbf{0 . 8 2}$ & $\mathbf{0 . 8 2}$ \\
\hline
\end{tabular}

The bold numbers indicate that the correlation coefficients are statistically significant at a confidence level of $>95 \%$ (i.e., $P$ value $<0.05$ ).

dissolution of most aerosol elements; otherwise, these anthropogenic elements should have remained approximately constant solubilities between the two periods. Taken together, the lifetime for the fine pollutant-dominated aerosols during the non-Asian dust period would be longer than that for the coarse dust-dominated aerosols during the Asian dust period. We thus ascribed this increased solubility in the non-Asian dust period to the aging process, which is, in fact, also involved with acid processing. That is because the aerosol particles, including mineral dust, become internally mixed with acidic substances as they age, which have been demonstrated well around the study region. In other words, these aged aerosol particles have been acidified largely, increasing the dissolution of aerosol elements. As a result, each of the three processes (aging, cloud, and acid processing) cannot be easily distinguished from the others.

\subsubsection{Other likely related factors: photochemical reaction and chemical speciation}

Photoreduction has been suggested to be a governing factor for solubilization of dust Fe and some specific aerosol elements, such as $\mathrm{Cu}$ and $\mathrm{Mn}$ during atmospheric transport (Zhu et al., 1993; Deguillaume et al., 2005). Zhu et al. (1997) observed an evident diel cycle of soluble Fe (II), with high daytime concentration and low nighttime concentration, in which the soluble (II) accounted for, on average, one-fourth of the dissolvable Fe. However, if organic and inorganic anions are both present in the reaction solutions, the dissolution of dust-associated Fe involving photochemical reactions would become more complicated, that is, not necessarily increasing the dissolution. For instance, Zhu et al. (1993) found that oxalate generated from the photochemical reaction of organic matters essentially of combustion origins may produce peroxide, which in turn oxidizes Fe (II), produced from photoreduction, to Fe (III). The solar irradiation stops at night, and notably, the Fe (II) freshly generated in daytime would be mostly oxidized back to Fe (III). Most of the samples in this study were integrated daily, such that the photochemical effect on the dissolution of aerosol elements cannot be exactly evaluated, although some elements were correlated well with WSOC comprising oxalate. In a nutshell, Zhu et al. (1997) concluded that the photochemical process do not have a substantial effect on the dissolution of dust Fe.

Another likely important factor of aerosol element dissolution is that a given element may exist in different chemical forms, that is, either as refractory or labile, in the aerosol particles (Hlavay et al., 1998; Qureshi et al., 2006). Results showing that the solubilities for aerosol elements are not correlated well with their corresponding crustal EF values may indicate that the chemical speciation often appears to be more effective than elemental origins for the dissolution of aerosol elements. For example, Sr and Mn, with respective mean crustal EF values of 2-3 and 3-4, are dominated by the crustal source; in contrast, Sn and Mo, with respective EF values of $\sim 50$ and $\sim 30$, are dominated by anthropogenic sources. However, the solubility for Sr and Mn reached $\geq 50 \%$ and $~ 50 \%$, respectively. For Sn and Mo, on the other hand, it was only $\leq 10 \%$ or $\sim 20 \%$. Chester et al. $(1993 \mathrm{a}$,b) linked the crustal/non-crustal source control on trace metal solubility to the solid state speciation of aerosol metals. Furthermore, they established a clear relationship between the extent to which a trace metal is soluble and the extent to which it is speciated into the exchangeable phase in aerosols. Unfortunately, they considered a limited number of elements (e.g., $\mathrm{Al}, \mathrm{Fe}, \mathrm{Mn}, \mathrm{Cu}, \mathrm{Zn}$, and $\mathrm{Pb}$ ). Both crustally derived $\mathrm{Al}$ and Fe essentially existed within the crystalline phase association, and thus, had a solubility of only $\sim<10 \%$. For Mn, its exchangeable association made up $20-40 \%$ of the total, consistent with our results showing high solubility ( $50 \%)$ for Mn. To our understanding, no chemical speciation data for ambient aerosol Sn and Mo are available. However, it is interesting that $\mathrm{Sn}$ in sediments (Boughriet et al., 2007; Yuan et al., 2004) and coal ash (Querol et al., 2000) mostly ( 98\%) partitions within the insoluble crystalline phase. Atmospheric Sn concentrations in Beijing sometimes reached several tens $\mathrm{ng} / \mathrm{m}^{3}$, and it was suggested to be mainly originating from coal combustion and waste incineration (Lei et al., 2004).

\subsubsection{The dry deposition fluxes of dissolvable TEs, $P$, Si, and $N$ in the ECS}

Because of the limitation of summertime samples available in this study and the prevalence of Asian dust and pollutant outflows particularly in winter and spring, only springtime and winter data were considered as a whole in representing the northeasterly monsoon period. Then, the dry deposition fluxes during this period were roughly estimated as follows:

$F=V_{\mathrm{d}} \times C_{\mathrm{a}}$

where $V_{\mathrm{d}}$ is the dry deposition velocity and $C_{\mathrm{a}}$ is the atmospheric concentration of aerosol species. For convenience, dry deposition velocities for individual species were assumed to be constant: $2 \mathrm{~cm} / \mathrm{s}$ for dust derived elements $\mathrm{Al}, \mathrm{Fe}, \mathrm{Si}, \mathrm{Ti}, \mathrm{Rb}, \mathrm{Sr}$, and Y; $1 \mathrm{~cm} / \mathrm{s}$ for certain elements of anthropogenic/natural mixed origins, including $\mathrm{Mn}, \mathrm{Co}$ Ba, Ni, Cr, V (Chen et al., 2008), and nitrate (considering a major portion of nitrate likely existing as coarse sodium nitrate through acid replacement) (de Leeuw et al., 2003); $0.5 \mathrm{~cm} / \mathrm{s}$ for other trace elements and P as well; and $0.2 \mathrm{~cm} / \mathrm{s}$ for ammonium. The dry deposition velocity of $2 \mathrm{~cm} / \mathrm{s}$ for the typical dust tracer, that is, $\mathrm{Al}$, is assumed to be identical to our estimate based on a long-term measurement of its size distribution in

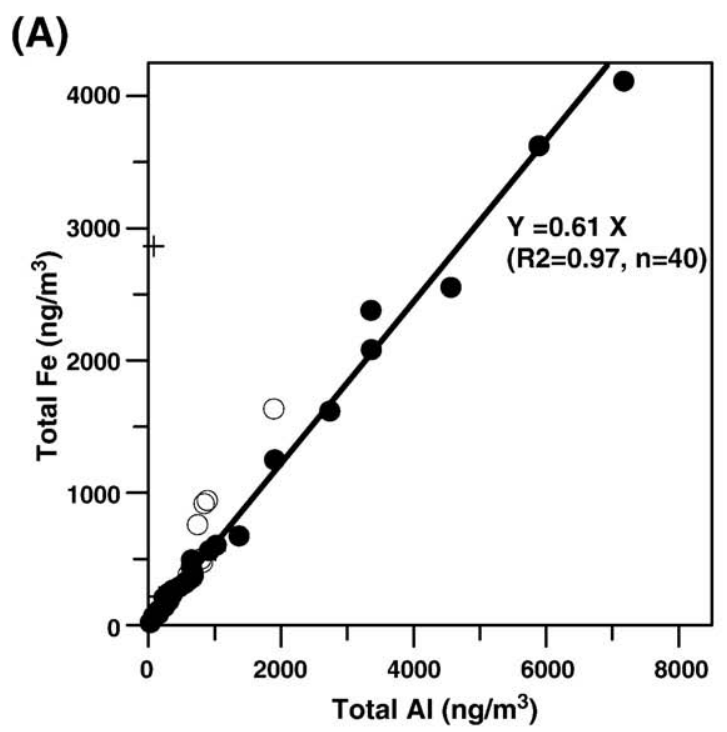

(B)

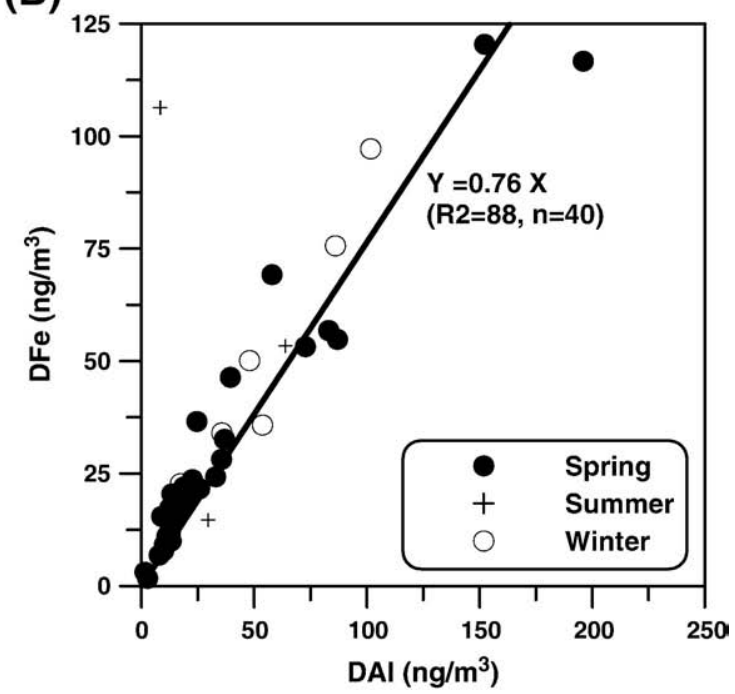

Fig. 5. Correlations of $\mathrm{Al}$ and $\mathrm{Fe}$ in the total fraction (A) and dissolvable fraction (B), respectively. The linear regression considers both spring and winter samples, but excluding the summer samples. 


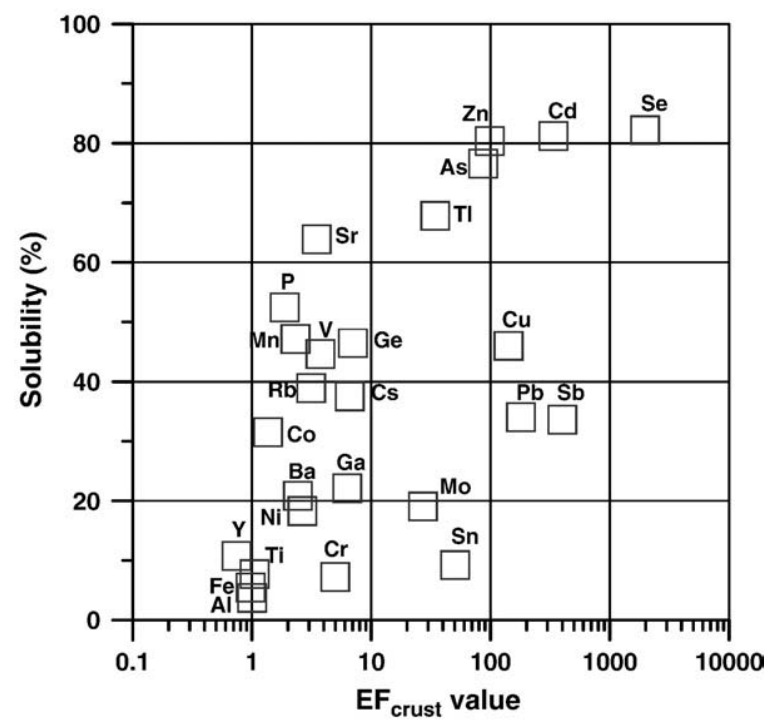

Fig. 6. The scatter plot of solubility and crustal EF value (in logarithmic scale) for all selected elements. northern Taiwan (Hsu et al., 2008c). Thus, we assumed other dust-dominated elements have the same velocity. Chen et al. (2008) also adopted a velocity of $1 \mathrm{~cm} / \mathrm{s}$ for the dust/ anthropogenic mixed source-dominated elements, as given in Table 9. However, in the case of anthropogenically derived elements, a wide range of velocities from as small as $0.1 \mathrm{~cm} / \mathrm{s}$ (Chen et al., 2008) to nearly $1 \mathrm{~cm} / \mathrm{s}$ (Spokes et al., 2001) was assigned. We used an intermediate value of $0.5 \mathrm{~cm} / \mathrm{s}$, which is also comparable with a mean value $(0.36 \mathrm{~cm} / \mathrm{s})$ used in Chen et al. (2008). For nitrate and ammonium, de Leeuw et al. (2003) used 2 and $0.1 \mathrm{~cm} / \mathrm{s}$, respectively, while our study used 1 and $0.2 \mathrm{~cm} / \mathrm{s}$, respectively. For phosphors, we assigned a velocity of $0.5 \mathrm{~cm} / \mathrm{s}$, but Chen and Chen used $2 \mathrm{~cm} / \mathrm{s}$ and Chen et al. (2008) used $1 \mathrm{~cm} / \mathrm{s}$.

As a consequence, the dry deposition fluxes for these selected species were yielded, as given in Table 9. For comparison, we also compiled two literature datasets on the dry deposition fluxes as well as the used dry deposition velocities for selected trace elements in marine aerosols in Table 9. The dry deposition flux of $\mathrm{Fe}_{\mathrm{s}}$ is also calculated to be $39 \pm 50 \mu \mathrm{g} /$ $\mathrm{m}^{2} / \mathrm{d}\left(0.69 \pm 0.89 \mu \mathrm{M} / \mathrm{m}^{2} / \mathrm{d}\right)$. When compared to that derived for the Chinese marginal seas from the modeling calculation (Gao et al., 2003), they are fairly comparable. For the total inorganic nitrogen (sum of nitrate nitrogen and ammonium nitrogen), the dry deposition fluxes are $0.79 \pm 0.95 \mathrm{mg} / \mathrm{m}^{2} / \mathrm{d}\left(56 \pm 68 \mu \mathrm{M} / \mathrm{m}^{2} / \mathrm{d}\right)$, which are also consistent with the published values (Nakamuraa et al., 2005). Note that dry deposition of gaseous species, such as nitrogen oxides and nitric acid, also probably contribute a significant fraction of atmospheric deposition of total inorganic nitrogen. Hence, the derived nitrogen flux represents the particulate inorganic nitrogen rather than the total nitrogen. For $P_{\mathrm{s}}$, the derived dry deposition in the northeasterly monsoon periods is $3.3 \pm 3.2 \mu \mathrm{g} / \mathrm{m}^{2} / \mathrm{d}$. Chen and Chen (2008) obtained a yearly dry deposition of total P to be $11.4 \mathrm{mg} / \mathrm{m}^{2}$. This corresponds to a deposition flux of $31 \mu \mathrm{g} / \mathrm{m}^{2} / \mathrm{d}$ regardless of the seasonal variation, in which they used a dry deposition velocity of $2 \mathrm{~cm} / \mathrm{s}$, as compared to the $0.5 \mathrm{~cm} / \mathrm{s}$ we used. Therefore, the inconsistency in the estimate of $\mathrm{P}$ dry deposition is caused mainly by the difference in the

(B)

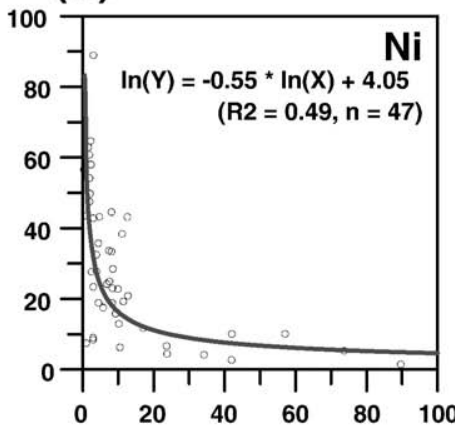

(D)

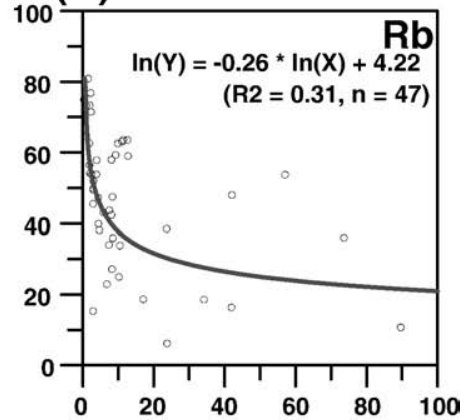

(F)

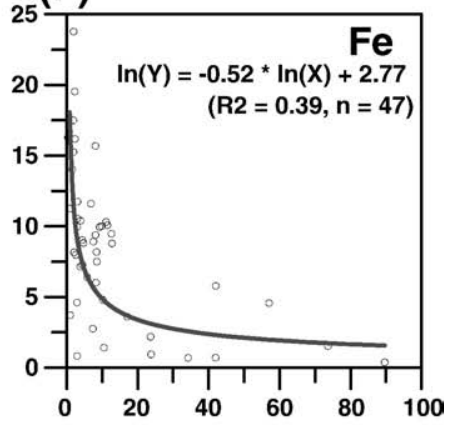

Dust concentration $\left(\mu \mathrm{g} / \mathrm{m}^{3}\right)$

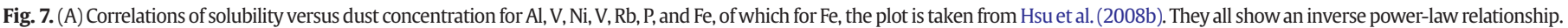



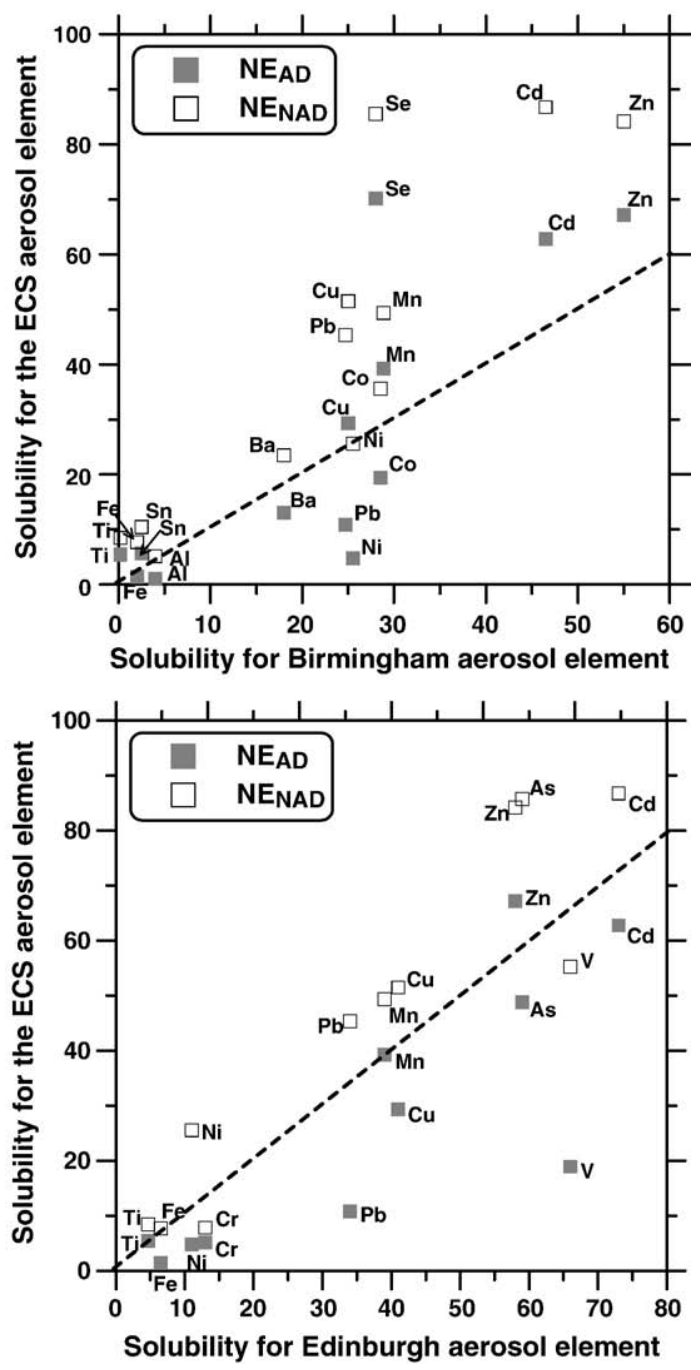

Fig. 8. Comparisons between our data on aerosol elemental solubilities (including two groups: $\mathrm{NE}_{\mathrm{AD}}$ and $\mathrm{NE} \mathrm{NAD}_{\mathrm{NA}}$ ) with literature data from two UK cities: (A) Birmingham (Birmili et al., 2006), and (B) Edinburgh (Heal et al., 2005). For the two referenced studies, the soluble fraction of aerosol metals was also determined with Milli-Q water extraction of aerosol-laden filters. In the former study, the filters were extracted under mechanical agitation for $20 \mathrm{~min}$ and then settled overnight; in the latter study, the filters were ultrasonically extracted for $1 \mathrm{~h}$. They are essentially similar to that we adopted in this study.

dry deposition velocity used and by the fact that the $\mathrm{P}_{\mathrm{S}}$ constitutes one twice that of the $\mathrm{P}_{\mathrm{T}}$. They also suggested that approximately a half $(46 \pm 38 \%)$ of total P may be sourced from biomass burning, which reveals that they may overestimate the velocity as the biomass burning aerosols essentially exist within fine particles. Because the samples (especially springtime samples) used for calculating the fluxes were mostly collected around the southern part of the ECS, they then might be underestimated somewhat once the derived dry deposition is applied for the entire ECS, as the northern part would receive more deposition than the southern part.

Apart from Fe, several other elements such as $\mathrm{Zn}, \mathrm{Cu}, \mathrm{Mn}, \mathrm{Ba}, \mathrm{Co}, \mathrm{V}, \mathrm{Ni}$, and $\mathrm{Cd}$ are also potentially essential to the phytoplankton (Whitfield, 1998; Butler, 1998; Morel and Price, 2003; Schulz et al., 2004). Their total deposition fluxes reach up to $41 \pm 74 \mu \mathrm{g} / \mathrm{m}^{2} / \mathrm{d}$. Certainly, current investigations on the atmospheric contributions of nutrient WSTEs focused on dust Fe and may have overlooked other trace elements. In general, nutrient trace metals of an anthropogenic origin are mostly associated within fine particles, which would be transported farther from the source regions compared to nutrient dust transportation. This would result in lower spatial variability for anthropogenic species than dust and associated Fe on a regional or global scale. Thus, it implies that the atmospheric inputs of bioavailable WSTEs to the biological stimulation would be much more significant in the remote Pacific Ocean than in the marginal and coastal seas of the western Pacific Ocean.

\section{Summary and concluding remarks}

The East China Sea is under the substantial influence of Asian outflow of eolian dust and air pollutants. During the Asian dust episodes, the loadings of various aerosol elements and components largely increased relative to those in the normal days, demonstrating the intense coupling of long-range transport of Asian dust and anthropogenic substances out of mainland China. The PCA analytical results show four major sources of aerosol elements, namely, Asian dust, biofuel/coal combustion, heavy fuel combustion, and sea salt, of which the first three components involve long-range transport. In terms of derived solubility, the analyzed elements could be grouped into four classes: (1) $\leq 20 \%$, including $\mathrm{Al}, \mathrm{Fe}$, $\mathrm{Ti}, \mathrm{Cr}, \mathrm{Y}, \mathrm{Sn}, \mathrm{Ba}, \mathrm{Ni}, \mathrm{Ga}$, and Mo; (2) 20\%-40\%, including Co, Cs, Rb, Sb, and $\mathrm{Pb}$; (3) 40\%-60\%, including $\mathrm{Mn}, \mathrm{V}, \mathrm{Cu}, \mathrm{Ge}$, and $\mathrm{P}$; and (4) $\geq 60 \%$, including $\mathrm{Tl}, \mathrm{Sr}, \mathrm{As}, \mathrm{Zn}, \mathrm{Cd}$, and Se.

In this study, we demonstrated that acid processing could overall be the most important factor controlling the aerosol elemental solubilization during long-range transport, and these are based on two facts: (1) that there were good correlations between almost all WSTEs of not only dust origin but also of anthropogenic origin and three acid species (i.e., nss-sulfate, nitrate and WSOC), and (2) that solubilities for anthropogenically derived elements were higher in the non-Asian dust period than the Asian dust period (indicating that aging processing involving acid processing accounted for this increase).

There was no strong relationship between crustal EF value and solubility for each element, indicating that the dissolution is not only the function of sources but also of other factors like chemical speciation. The $\mathrm{Al}_{\mathrm{T}}$ maximized during the Asian dust episode and thereafter decreased greatly, while the solubility (and sometimes $\mathrm{Al}_{\mathrm{S}}$ concentration) significantly increased after the weakening of Asian dust, hypothesizing that aging/cloud processing also involving acid processes account for the increasing tendency. Moreover, for a few of the metals and phosphorus,

\section{Table 9}

The estimated dry deposition fluxes (DDF; $\mu \mathrm{g} / \mathrm{m}^{2} / \mathrm{d}$, but $\mathrm{mg} / \mathrm{m}^{2} / \mathrm{d}$ for nitrogen) for WSTEs, phosphorus, silicon, as well as inorganic nitrogen (ammonium and nitrate associated nitrogen)

\begin{tabular}{|c|c|c|c|c|c|c|c|}
\hline & \multicolumn{2}{|c|}{$\begin{array}{l}\text { The East China Sea } \\
\text { (This work) }\end{array}$} & \multicolumn{2}{|c|}{$\begin{array}{l}\text { The Gulf of } \\
\text { Aqaba, Red Sea } \\
\text { (Chen et al., 2008) }\end{array}$} & \multicolumn{2}{|c|}{$\begin{array}{l}\text { Northeast } \\
\text { Atlantic Ocean } \\
\text { (Spokes et al., } \\
\text { 2001) }\end{array}$} & \multirow{2}{*}{$\begin{array}{l}\text { Northwestern } \\
\text { Mediterranean } \\
\text { (Guieu et al., 1997) } \\
\begin{array}{l}\text { TDF } \\
\text { (dissolved Mean) }\end{array}\end{array}$} \\
\hline & $\overline{\mathrm{DDV}}$ & $\begin{array}{l}\text { DDF (soluble) } \\
\text { Mean } \pm \text { S.D. }\end{array}$ & DDV & $\begin{array}{l}\text { DDF (total) } \\
\text { Mean }\end{array}$ & $\overline{\mathrm{DDV}}$ & $\begin{array}{l}\text { DDF (total) } \\
\text { Mean }\end{array}$ & \\
\hline$\overline{\mathrm{Al}}$ & 2.0 & $40 \pm 71$ & 1.0 & 936 & 1.3 & 14 & $28-279$ \\
\hline $\mathrm{Fe}$ & 2.0 & $39 \pm 50$ & 1.0 & 591 & - & - & $88-384$ \\
\hline $\mathrm{Ti}$ & 2.0 & $6.0 \pm 8.4$ & - & - & - & - & - \\
\hline $\mathrm{Ba}$ & 1.0 & $1.4 \pm 2.1$ & - & - & - & - & - \\
\hline Mn & 1.0 & $6.7 \pm 14.3$ & 1.0 & 14.5 & 1.25 & 2.2 & $7.7-33$ \\
\hline V & 1.0 & $1.5 \pm 4.0$ & 1.0 & 4.67 & - & - & - \\
\hline $\mathrm{Rb}$ & 2.0 & $1.4 \pm 3.2$ & - & - & - & - & - \\
\hline $\mathrm{Ni}$ & 1.0 & $0.24 \pm 0.29$ & 0.36 & 0.86 & - & - & $1.1-1.4$ \\
\hline $\mathrm{Cr}$ & 1.0 & $0.23 \pm 0.22$ & 1.0 & 2.63 & - & - & $0.25-1.1$ \\
\hline Co & 1.0 & $0.069 \pm 0.092$ & 1.0 & 0.28 & - & - & $0.05-0.36$ \\
\hline Y & 2.0 & $0.034 \pm 0.065$ & - & - & - & - & - \\
\hline Cs & 2.0 & $0.10 \pm 0.28$ & - & - & - & - & - \\
\hline $\mathrm{Cu}$ & 0.5 & $12 \pm 14$ & 0.36 & 1.05 & - & - & $2.2-3.6$ \\
\hline $\mathrm{Zn}$ & 0.5 & $19 \pm 39$ & 0.36 & 4.61 & 0.82 & 9.5 & $1.9-205$ \\
\hline $\mathrm{Pb}$ & 0.5 & $2.5 \pm 6.7$ & 0.36 & 2.18 & 0.50 & 3.4 & $2.5-5$ \\
\hline As & 0.5 & $0.39 \pm 0.63$ & - & - & - & - & - \\
\hline $\mathrm{Se}$ & 0.5 & $0.27 \pm 0.48$ & - & - & - & - & - \\
\hline $\mathrm{Cd}$ & 0.5 & $0.19 \pm 0.37$ & 0.36 & 0.03 & - & - & $28-279$ \\
\hline $\mathrm{Sb}$ & 0.5 & $0.087 \pm 0.19$ & - & - & - & - & - \\
\hline $\mathrm{Ga}$ & 0.5 & $0.067 \pm 0.12$ & - & - & - & - & - \\
\hline Sn & 0.5 & $0.030 \pm 0.051$ & - & - & - & - & - \\
\hline $\mathrm{Tl}$ & 0.5 & $0.034 \pm 0.078$ & - & - & - & - & - \\
\hline $\mathrm{Ge}$ & 0.5 & $0.016 \pm 0.035$ & - & - & - & - & - \\
\hline Mo & 0.5 & $0.027 \pm 0.091$ & - & - & - & - & - \\
\hline $\mathrm{Si}$ & 2.0 & $10 \pm 6.2$ & - & - & - & - & - \\
\hline $\mathrm{P}$ & 0.5 & $3.3 \pm 3.2$ & 1.0 & 11.6 & - & - & - \\
\hline $\mathrm{NO}_{3}^{-}-\mathrm{N}$ & 1.0 & $0.54 \pm 0.71$ & - & - & - & - & - \\
\hline $\mathrm{NH}_{4}^{+}-\mathrm{N}$ & 0.2 & $0.25 \pm 0.24$ & - & - & - & - & - \\
\hline
\end{tabular}

Also shown is the dry deposition velocity (DDV, $\mathrm{cm} / \mathrm{s}$ ) adopted in calculations. Three literature data sets are given here for comparison: two for the dry deposition fluxes of the total trace elements in marine aerosols and their DDV used; one for the total deposition (including dry and wet deposition) fluxes (TDF) of dissolved metals. 
the correlations between the solubility and dust concentration displayed an inverse power-law relationship. Consequently, we could conclude that the importance of each controlling factor may follow this sequence: acid processing (atmospheric processing) $>$ chemical speciation $\approx$ initial composition (elemental sources) > dust loading, of which the relative importance between chemical speciation and initial composition seems to be dependent upon which aerosol element is of interest. The effect of atmospheric processing on the dissolution of aerosol elements is more important to the crustally derived elements than to the anthropogenically derived elements. Nevertheless, we did not find any single process that could fully describe the dissolution of aerosol elements. More complex controlling factors may be involved in the dissolution of aerosol elements, which eventually determine their fate. A better understanding of dissolution processes and the solubility of aerosol-bound elements will facilitate more precise estimations of the impact of trace metal atmospheric depositions.

The yielded dry deposition flux for $\mathrm{Fe}_{\mathrm{S}}$ in the northeasterly monsoon is $39 \pm 50 \mu \mathrm{g} / \mathrm{m}^{2} / \mathrm{d}$. The sum of those potential nutrient elements, including $\mathrm{Zn}, \mathrm{Cu}, \mathrm{Mn}, \mathrm{Ba}, \mathrm{Co}, \mathrm{V}, \mathrm{Ni}$, and $\mathrm{Cd}$, is $41 \pm 74 \mu \mathrm{g} / \mathrm{m}^{2} / \mathrm{d}$, which is highly comparable with that of $\mathrm{Fe}_{\mathrm{S}}$. This highlights the notion that atmospheric deposition could also be a significant source of these bioavailable trace elements, though most common studies emphasized the importance of eolian Fe. More importantly, WSTEs can be present all year round and not only during Asian dust episodes and are usually associated within fine-sized particles such that they would be transported to a larger extent than coarse dust-associated elements. In addition to nutrient inputs, atmospheric deposition also supply tremendous amounts of toxic chemical species, such as $\mathrm{Pb}, \mathrm{As}, \mathrm{Se}, \mathrm{Sn}, \mathrm{Sb}$, and $\mathrm{Tl}$ to poison the marine organisms and disturb their biogeochemical cycles in the ECS, which need to be quantitatively evaluated in future.

\section{Acknowledgment}

We are grateful to two anonymous reviewers and Prof. Sedwick for their constructive suggestions and comments. We would like to thank the technicians and crew of R/V ORI and R/V ORII, Prof. L.S. Wen of National Taiwan University, Prof. T.M. Hsiung and Prof. H.Y. Chen of National Taiwan Ocean University, and W.L. Yang, Q.Z. Ye, Y.F. Tzeng, and X.Y. Kuo for their assistance with sampling. We would also like to thank J. Chien, Z.S. Lu, Z.J. Wu, C.L. Kuo, and A.J. Chung for helping in chemical analysis. The authors would also like to extend their gratitude to the NOAA Air Resources Laboratory (ARL) for the provision of the HYSPLIT transport and dispersion model and READY Web site (http://www.arl.noaa.gov/ready.html) used in this publication. This work was supported by National Science Council (R.O.C.) grants NSC 94-2811-M001-001, NSC 95-2811-M001-018, NSC 962611-M001-001, and NSC 96-2611-M001-004 and partly by the Center for Marine Bioscience and Biotechnology, NTOU, and the thematic program, Atmospheric Forcing on Ocean Biogeochemistry, of Academia Sinica to S.C.H.

\section{References}

Baker, A.R., Jickells, T.D., 2006. Mineral particle size as a control on aerosol iron solubility. Geophys. Res. Lett. 33, L17608. doi:10.1029/2006GL026557.

Baker, A.R., Kelly, S.D., Biswas, K.F., Witt, M., Jickells, T.D., 2003. Atmospheric deposition of nutrients to the Atlantic Ocean. Geophys. Res. Lett. 30 (24), 2296. doi:10.1029/ 2003GL018518

Baker, A.R., Jickells, T.D., Witt, M., Linge, K.L., 2006. Trends in the solubility of iron, aluminum, manganese and phosphorus in aerosol collected over the Atlantic Ocean. Mar. Chem. $98,43-58$.

Birmili, W., Allen, A.G., Bary, F., Harrison, R.M., 2006. Trace metal concentrations and water solubility in size-fractionated atmospheric particles and influence of road traffic. Environ. Sci. Technol. 40, 1144-1153.

Bishop, J.K.B., Davis, R.E., Sherman, J.T., 2002. Robotic observations of dust storm enhancement of carbon biomass in the North Pacific. Science 298, 817-821.

Bonnet, S., Guieu, C., 2004. Dissolution of atmospheric iron in seawater. Geophys. Res. Lett. 31, L03303. doi:10.1029/2003GL018423.
Boughriet, A., Proix, N., Billon, G., Recourt, P., Ouddane, B., 2007. Environmental impacts of heavy metal discharges from a smelter in Deûle-canal sediments (northern France): concentration levels and chemical fractionation. Water Air Soil Pollut. 180, 83-95.

Buck, C.S., Landing, W.M., Resing, J.A., Lebon, G.T., 2006. Aerosol iron and aluminum solubility in the northwest Pacific Ocean: results from the 2002 IOC cruise. Geochem. Geophys. Geosyst. 7, Q04M07. doi:10.1029/2005GC000977.

Butler, A., 1998. Acquisition and utilization of transition metal ions by marine organisms. Science 281, 207-210.

Carmichael, G.R., Streets, D.G., Calori, G., Amann, M., Jacobson, M.Z., Hansen, J., Ueda, H., 2002. Changing trends in sulfur emissions in Asia: implications for acid deposition, air pollution, and climate. Environ. Sci. Technol. 36, 4707-4713.

Chen, H.Y., Chen, L.T., 2008. The importance of anthropogenic inputs and continentalderived dust for the distribution and flux of water-soluble nitrogen and phosphorus species in aerosol within the atmosphere over the East China Sea. J. Geophys. Res. 113, D11303. doi:10.1029/2007JD009491.

Chen, Y., Siefert, R.L., 2004. Seasonal and spatial distributions and dry deposition fluxes of atmospheric total and labile iron over the tropical and sub-tropical North Atlantic Ocean. J. Geophys. Res. 109, D09305. doi:10.1029/2003JD003958.

Chen, L.L., Carmichael, G.R., Hong, M.S., Ueda, H., Shim, S., Song, C.H., Kim, Y.P., Arimoto, R., Prospero, J., Savoie, D., Murano, K., Park, J.K., Lee, H.G., Kang, C., 1997. Influence of continental outflow events on the aerosol composition at Cheju Island, South Korea. J. Geophys. Res. 102, 28551-28574.

Chen, Y., Street, J., Paytan, A., 2006. Comparison between pure-water- and seawater-soluble nutrient concentrations of aerosols from the Gulf of Aqaba. Mar. Chem. 101, 141-152.

Chen, Y., Paytan, A., Chase, Z., Measures, C., Beck, A.J., Sañudo-Wilhelmy, S.A., Pos, A.F., 2008. Sources and fluxes of atmospheric trace elements to the Gulf of Aqaba, Red Sea. J. Geophys. Res. 113, D05306. doi:10.1029/2007JD009110.

Chester, R., Murphy, K.J.T., Lin, F.J., Berry, A.S., Bradshaw, G.A., Corcoran, P.A., 1993a. Factors controlling the solubilities of trace metals from non-remote aerosols deposited to the sea surface by the 'dry' deposition mode. Mar. Chem. 42, 107-126.

Chester, R., Nimmo, M., Alarcon, M., Saydam, C., Murphy, K.J.T., Sanders, G., Corcoran, P.A., 1993b. Defining the chemical character of aerosols from the atmosphere of the Mediterranean Sea and surrounding regions. Oceanol. Acta 16, 231-246.

Chester, R., Nimmo, M., Corcoran, P.A., 1997. Rain water aerosol trace metal relationships at Cap Ferrat: a coastal site in the western Mediterranean. Mar. Chem. 58, 293-312.

Chester, R., Nimmo, M., Fones, G.R., Keyse, S., Zhang, J., 2000a. The solubility of Pb in coastal marine rainwaters: pH dependent relationships. Atmos. Environ. 34, 3875-3887.

Chester, R., Nimmo, M., Fones, G.R., Keyse, S., Zhang, J., 2000b. Trace metal chemistry of particulate aerosols from the UK mainland coastal rim of the NE Irish Sea. Atmos. Environ. 34, 949-958.

Davison, W., Arewgoda, C.M., Hamilton-Taylor, J., Hewitt, C.N., 1994. Kinetics of dissolution of lead and zinc from rural atmospheric aerosols in fresh-water and synthetic solutions. Water Res. 28, 1703-1709.

Deguillaume, L., Leriche, M., Desboeufs, K., Mailhot, G., George, C., Chaumerliac, N., 2005. Transition metals in atmospheric liquid phases: sources, reactivity, and sensitive parameters. Chem. Rev. 105, 3388-3431.

de Leeuw, G., et al., 2003. Atmospheric nitrogen inputs into the North Sea: effect on productivity. Cont. Shelf Res. 23, 1743-1755.

Desboeufs, K.V., Losno, R., Vimeux, F., Cholbi, S., 1999. The pH-dependent dissolution of wind-transported Saharan dust. J. Geophys. Res. 104, 21287-21299.

Desboeufs, K.V., Losno, R., Colin, J.L., 2001. Factors influencing aerosol solubility during cloud processes. Atmos. Environ. 35, 3529-3537.

Desboeufs, K.V., Sofikitis, A., Losno, R., Colin, J.L., Ausset, P., 2005. Dissolution and solubility of trace metals from natural and anthropogenic aerosol particulate matter. Chemosphere 58, 195-203.

Duce, A., et al., 1991. The atmospheric input of trace species to the world oceans. Global Biogeochem. Cycles 5, 193-259.

Gao, Y., Kaufman, Y.J., Tanre, D., Kolber, D., Falkowski, P.G., 2001. Seasonal distributions of aeolian iron fluxes to the global ocean. Geophys. Res. Lett. 28, 29-32.

Gao, Y., Fan, S.M., Sarmiento, J.L., 2003. Aeolian iron input to the ocean through precipitation scavenging: a modeling perspective and its implication for natural iron fertilization in the ocean. J. Geophys. Res. 108 Art. No. 4221.

Graedel, T.E., Mandich, M.L., Weschler, C.J., 1986. Kinetic model studies of atmospheric droplet chemistry, 2. Homogeneous transition metal chemistry in raindrops. J. Geophys. Res. 91, 5221-5225.

Guerzoni, S., Molinaroli, E., Rossini, P., Rampazzo, G., Quarantotto, G., de Falco, G., Cristini, S., 1999. Role of desert aerosol in metal fluxes in the Mediterranean area. Chemosphere 39, 229-246.

Guieu, C., Duce, R., Arimoto, R., 1994. Dissolved input of manganese to the ocean-aerosol source. J. Geophys. Res. 99, 18789-18800.

Guieu, C., Chester, R., Nimmo, M., Martin, J.-M., Guerzoni, S., Nicolas, E., Mateu, J., Keyse, S., 1997. Atmospheric input of dissolved and particulate metals to the northwestern Mediterranean. Deep-Sea Res. II 44, 655-674.

Heal, M.R., Hibbs, L.R., Agius, R.M., Beverland, I.J., 2005. Total and water-soluble trace metal content of urban background $\mathrm{PM}_{10}, \mathrm{PM}_{25}$ and black smoke in Edinburgh, UK. Atmos. Environ. 39, 1417-1430.

Hlavay, J., Polyák, K., Molnár, A., Mészáros, E., 1998. Determination of the distribution of elements as a function of particle size in aerosol samples by sequential leaching. Analyst 123, 859-863.

Hsu, S.C., Liu, S.C., Lin, C.Y., Hsu, R.T., Huang, Y.T., Chen, Y.W., 2004. Metal compositions of $\mathrm{PM}_{10}$ and $\mathrm{PM}_{25}$ aerosols in Taipei during spring. 2002. Terres. Atmos. Ocean. Sci. 15, 925-948.

Hsu, S.C., Lin, F.J., Jeng, W.L., 2005a. Seawater solubility of marine aerosols associated natural and anthropogenic metals. Atmos. Environ. 39, 3989-4001.

Hsu, S.C., Liu, S.C., Jeng, W.L., Lin, F.J., Huang, Y.T., Lung, C.S.C., Liu, T.H., Tu, J.Y., 2005b. Variations of $\mathrm{Cd} / \mathrm{Pb}$ and $\mathrm{Zn} / \mathrm{Pb}$ ratios in Taipei aerosols reflecting long-range transport or local pollution emissions. Sci. Total Environ. 347, 111-121. 
Hsu, S.C., Liu, S.C., Jeng, W.L., Chou, C.C.K., Hsu, R.T., Hung, Y.T., Chen, Y.W., 2006. Lead isotope ratios in ambient aerosols from Taipei, Taiwan: assessing the impacts of long-range transport from the Yangtze Delta. Atmos. Environ. 40, 5393-5404.

Hsu, S.C., Liu, S.C., Kao, S.J., Jeng, W.L., Huang, Y.T., Tseng, C.M., Tsai, F., Tu, J.Y., Yang, Y., 2007. Water soluble species in the marine aerosol from the northern South China Sea: High chloride depletion related to air pollution. J. Geophys. Res. 112. doi:10.1029/ 2007JD008844.

Hsu, S.C., Liu, S.C., Huang, Y.T., Lung, S.C.C., Tsai, F., Tu, J.Y., Kao, S.J., 2008a. A criterion for identifying Asian dust events based on Al concentration data collected from northern Taiwan between 2002 and early 2007. J. Geophys. Res. 113, D18306. doi:10.1029/2007JD009574.

Hsu, S.C., Liu, S.C., Huang, Y.T., Kao, S.J., Gong, G.C., Shiah, F.K., Kao, S.J., Lin, F.J., Lung, C.S.C. Chen, J.P., 2008b. Dissolution of Asian dust iron during long-range transport: effects of atmospheric processing, transport history, and dust and sea salt loadings. Global Biogeochem. Cycles (in review).

Hsu, S.C., Liu, S.C., Arimoto, R., Liu, T.H., Huang, Y.T., Tsai, F., Lin, F.J., 2008c. Dust deposition to the East China Sea and its biogeochemical implications. J. Geophys. Res. (in revision).

Jickells, T.D., et al., 2005. Global iron connections between desert dust, ocean biogeochemistry and climate. Science 308, 67-71.

Kersten, M., Kriews, M., Forstner, U., 1991. Partitioning of trace metals released from polluted marine aerosols in coastal seawater. Mar. Chem. 36, 165-182.

Kocak, M., Nimmo, M., Kubilay, N., Herut, B., 2004. Spatio-temporal aerosol trace metal concentrations and sources in the Levantine Basin of the Eastern Mediterranean. Atmos. Environ. 38, 2133-2144.

Lei, C., Landsberger, S., Basunia, S., Tao, Y., 2004. Study of $\mathrm{PM}_{2.5}$ in Beijing suburban site by neutron activation analysis and source apportionment. J. Radioanal. Nucl. Chem. 261, 87-94.

Lim, B., Jickells, T.D., Colin, J.L., Losno, R., 1994. Solubilities of $\mathrm{Al}, \mathrm{Pb}, \mathrm{Cu}$, and $\mathrm{Zn}$ in rain sampled in the marine environment over the North Atlantic Ocean and Mediterranean Sea. Global Biogeochem. Cycles 8, 349-362.

Lin, F.J., Hsu, S.C., Jeng, W.L., 2000. Lead in the southern East China Sea. Mar. Environ. Res. 49, 329-342.

Lin, C.Y., Liu, S.C., Chou, C.C.K., Huang, S.J., Liu, C.M., Kuo, C.H., Young, C.Y., 2005. Longrange transport of aerosols and their impact on the air quality of Taiwan. Atmos. Environ. 39, 6066-6076.

Liu, T.H., Tsai, F., Hsu, S.C., Hsu, C.C., Shiu, C.J., Chen, W.N., Tu, J.T., in press, Southeastward transport of Asian dust: source, transport and its contributions to Taiwan. Atmos. Environ. doi:10.1016/j.atmosenv.2008.07.066.

Mackie, D.S., Boyd, P.W., Hunter, K.A., McTainsh, G.H., 2005. Simulating the cloud processing of iron in Australian dust: $\mathrm{pH}$ and dust concentration. Geophys. Res. Lett. 32, L06809. doi:10.1029/2004GL022122.

Meskhidze, N., Chameides, W.L., Nenes, A., 2005. Dust and pollution: a recipe for enhanced ocean fertilization? J. Geophys. Res. 110, D03301. doi:10.1029/2004JD005082.

Morel, F.M.M., Price, N.M., 2003. The biogeochemical cycles of trace metals in the oceans. Science 300, 944-947.

Nakamuraa, T., Matsumotob, K., Uematsu, M., 2005. Chemical characteristics of aerosols transported from Asia to the East China Sea: an evaluation of anthropogenic combined nitrogen deposition in autumn. Atmos. Environ. 39, 1749-1758.

Park, M.H., Kim, Y.P., Kang, C.H., Shim, S.G., 2004. Aerosol composition change between 1992 and 2002 at Gosan, Korea. J. Geophys. Res. 109, D19S13. doi:10.1029/2003JD004110.

Querol, X., Umaña, J.C., Alastuey, A., Bertrana, C., Lopes-Soler, A., Plana, F., 2000. Extraction of water-soluble impurities from fly ash. Energy Sources 22, 733-755.

Qureshi, S., Dutkiewicz, V.A., Khan, A.R., Swami, K., Yang, K.X., Husain, L., Schwab, J.J., Demerjian, K.L., 2006. Elemental composition of $\mathrm{PM}_{2.5}$ aerosols in Queens, New York: solubility and temporal trends. Atmos. Environ. 40, S238-S251.

Schulz, K.G., Zondervan, I., Gerringa, L.J.A., Timmermans, K.R., Veldhuis, M.J.W., Riebesell, U., 2004. Effect of trace metal availability on coccolithophorid calcification. Nature 430, 673-676.
Sedlak, D.L., Hoigne, H.J., David, M.M., Colvile, R.N., Sey! er, E., Acker, K., Wiepercht, W., Lind, J.A., Fuzzi, S., 1997. The cloudwater chemistry of iron and copper at Great Dun Fell, UK. Atmos. Environ. 31, 2515-2526.

Sedwick, P.N., Sholkovitz, E.R., Church, T.M., 2007. Impact of anthropogenic combustion emissions on the fractional solubility of aerosol iron: evidence from the Sargasso Sea. Geochem. Geophys. Geosyst. 8, Q10Q06. doi:10.1029/2007GC001586.

Spokes, L.J., Jickells, T.D., Lim, B., 1994. Solubilisation of aerosol trace metals by cloud processing: a laboratory study. Geochim. Cosmochim. Acta 58, 3281-3287.

Spokes, L., Jickells, T., Jarvis, K., 2001. Atmospheric inputs of trace metals to the northeast Atlantic Ocean: the importance of southeasterly flow. Mar. Chem. 76, 319-330.

Statham, P.J., Chester, R., 1988. Dissolution of manganese from atmospheric particulates into seawater and rainwater. Geochim. Cosmochim. Acta 52, 2433-2437.

Sullivan, R.C., Guazzotti, S.A., Sodeman, D.A., Prather, K.A., 2007. Direct observations of the atmospheric processing of Asian mineral dust. Atmos. Chem. Phys. 7, 1213-1236.

Taylor, S.R., 1964. Abundance of chemical elements in the continental crust: a new table. Geochim. Cosmochim. Acta 28, 1237-1285.

Waldman, J.M., Lioy, P.J., Zelenka, M., Jing, L., Lin, Y.N., He, Q.C., Qian, Z.M., Chapman, R., Wilson, W.E., 1991. Wintertime measurements of aerosol acidity and trace elements in Wuhan, a city in central China. Atmos. Environ. 25B, 113-120.

Wang, Y.X., McElroy, M.B., Wang, T., Palmer, P.I., 2004. Asian emissions of $\mathrm{CO}$ and $\mathrm{NO}_{x}$ : constraints from aircraft and Chinese station data. J. Geophys. Res. 109, D24304. doi:10.1029/2004JD005250.

Wei, F., Teng, E., Wu, G., Hu, W., Wilson, W.E., Chapman, R.S., Pau, J.C., Zhang, J., 1999. Ambient concentrations and elemental compositions of $\mathrm{PM}_{10}$ and $\mathrm{PM}_{2.5}$ in four Chinese cities. Environ. Sci. Technol. 33, 4188-4193.

Wen, H., Carignan, J., 2007. Reviews on atmospheric selenium: emissions, speciation and fate. Atmos. Environ. 41, 7151-7165.

Whitfield, M., 1998. Interactions between phytoplankton and trace metals in the ocean Adv. Mar. Biol. 41,1-128.

Wu, J., Rember, R., Cahill, C., 2007. Dissolution of aerosol iron in the surface waters of the North Pacific and North Atlantic oceans as determined by a semicontinuous flowthrough reactor method. Global Biogeochem. Cycles 21, GB4010. doi:10.1029/ 2006GB002851

Yuan, W., Zhang, J., 2006. High correlations between Asian dust events and biological productivity in the western North Pacific. Geophys. Res. Lett. 33, L07603. doi:10.1029/2005GL025174.

Yuan, C.G., Shi, J.B., He, B., Liu, J.F., Liang, L.N., Jiang, G.B., 2004. Speciation of heavy metals in marine sediments from the East China Sea by ICP-MS with sequential extraction. Environ. Int. 30, 769-783.

Zhang, X.Y., Arimoto, R., An, Z.S., 1997. Dust emission from Chinese desert sources linked to variations in atmospheric circulation. J. Geophys. Res. 102, 28041-28047.

Zhang, X.Y., Gong, S.L., Shen, Z.X., Mei, F.M., Xi, X.X., Liu, L.C., Zhou, Z.J., Wang, D., Wang, Y.Q., Cheng, Y., 2003. Characterization of soil dust aerosol in China and its transport and distribution during 2001 ACE-Asia: 1. Network observations. J. Geophys. Res. 108 (D9), 4261. doi:10.1029/2002JD002632.

Zhang, D., Iwasaka, Y., Shi, G., Zang, J., Hu, M., Li, C., 2005. Separated status of the natural dust plume and polluted air masses in an Asian dust storm event at coastal areas of China. J. Geophys. Res. 110, D06302. doi:10.1029/2004JD005305.

Zhu, X., Prospero, J.M., Savoie, D.L., Millero, F.J., Zika, R.G., Saltzman, E.S., 1993. Photoreduction of iron (III) in marine mineral aerosol solutions. J. Geophys. Res. 98, 9039-9046.

Zhu, X.R., Prospero, J.M., Millero, F.J., 1997. Diel variability of soluble Fe(II) and soluble total Fe in North African dust in the trade winds at Barbados. J. Geophys. Res. 102, 21297-21305.

Zhuang, G.S., Duce, R.A., Kester, D.R., 1990. The dissolution of atmospheric iron in surface seawater of the open ocean. J. Geophys. Res. 95, 16,207-16,216.

Zhuang, G.S., Yi, Z., Duce, R.A., Brown, P.R., 1992. Link between iron and sulfur cycles suggested by detection of $\mathrm{Fe}(\mathrm{II})$ in remote marine aerosols. Nature 355, 537-539.

Zuo, Y., 1995. Kinetics of photochemical/chemical cycling of iron coupled with organic substances in cloud and fog droplets. Geochim. Cosmochim. Acta 59, 3123-3130. 